NBER WORKING PAPER SERIES

FIXED AND FLEXIBLE RATES:

A RENEWAL OF THE DEBATE

Jacques R. Artus

John H. Young

Working Paper No. 367

NATIONAL BUREAU OF ECONOMIC RESEARCH

1050 Massachusetts Avenue

Cambridge MA 02138

June 1979 


\title{
Fixed and Flexible Rates: A Renewal of the Debate
}

Jacques R. Artus and John H. Young

\begin{abstract}
Summary
The paper reviews the extent to which a decade of analysis and experience has altered thinking about the choice of an exchange rate system. The advantages of flexible rates are viewed to have been exaggerated. They do not permit governments to have permanently higher rates of economic activity at the expense of higher inflation as some thought. Further, the slow speed of adjustment to relative price changes limits the contribution of flexible rates to external adjustment in the short-run, and the degree of insulation from external influences that they provide. Finally, flexible rates tend to be fluctuating rates, and, although there is little empirical evidence so far showing that the fluctuations have had adverse effects on trade and capital flows, the exchange rate instability more than any other factor has led to a certain disillusionment with the floating rate system. Notwithstanding the drawbacks of flexible rates, there will be a continuing need for exchange rate flexibility over the next few years, and some analysis is given of the problems of achieving greater stability under flexible rates or the requisite amount of flexibility under pegged rates.
\end{abstract}

Jacques R. Artus Research Department International Monetary Fund 70019 th Street, N.W. Washington, D.C. 20431 Tel. (202)477-7158 


\section{Fixed and Flexible Rates: A Renewal of the Debate}

Prepared by Jacques R. Artus and John H. Young

May 1, 1979

For some time the view has been developing that the flexible rate system has not accomplished as much as many of its supporters had hoped it would. More recently, in the discussions associated with the adoption of the European Monetary System, there has been a renewal of interest in the advantages and disadvantages of adopting some form of pegging. It may be time, therefore, to review the extent to which a decade of analysis and experience has altered thinking about the choice of an exchange rate system. As in the earlier debate, the discussion of fixed and flexible rates in recent years has been almost exclusively directed to the choice of exchange rate systems for developed countries, and the scope of this paper is similarly limited.

The case for a flexible exchange rate system was generally based on hopes of what would result, and the case against on fears of what might happen. Part I is directed to a critical analysis of some of the views widely held by adherents of flexible rates. It is pointed out that few today would defend flexible rates on the grounds that they permit governments to take advantage of a long-term trade-off between employment and wage increases, and thus make it possible for countries to have permanently

* The research reported here is part of the NBER's research program in international studies. Any opinions expressed are those of the authors and not those of the National Bureau of Economic Research.

The authors are members of the staff of the International Montary Fund, but the views presented in this paper are not to be interpreted as necessarily indicating the position of the Executive Board or of the officials of the Fund. 
higher rates of economic activity at the expense of higher inflation. It is also argued that many adherents of flexible rates gave inadequate weight to the slow speed of adjustment to relative price changes in the goods markets. They thus exaggerated the contribution that exchange rate changes would make in the short run to external adjustment, and similarly overestimated the extent to which flexible rates would insulate countries from external influences and leave them free to pursue domestic objectives through the use of domestic economic policies.

Part II takes a similarly critical approach to some of the fears raised by opponents of flexible rates. Some of the concerns are found to have had some basis, particularly the fear that flexible rates would tend to be fluctuating rates, and it is suggested that exchange rates might continue to show considerable instability even under relatively stable underlying economic and financial conditions. There is less empirical evidence to justify other concerns, namely that flexible rates would have adverse effects on trade and capital flows, but some of the most marked exchange rate instability has been too recent to show much effect as yet. Finally, a brief analysis is given of the complex and mixed relationship between flexible rates and inflation.

Part III draws together the main conclusions and discusses the search for greater exchange rate stability. It is pointed out that, notwithstanding the drawbacks of flexible rates, the nature of the conditions likely to exist in a number of member countries over the next few years will give rise to a continuing need for a measure of exchange rate flexibility, and some analysis is given of the problems of achieving the requisite amount of 
flexibility under pegged rates. The paper concludes with a brief discussion of the relationship between monetary policy and exchange rate stability. It is pointed out that keeping a close eye on external conditions in determining monetary policy can help in setting limits to short-run exchange rate instability, and that some national monetary authorities are already giving greater weight than in the past to existing or potential exchange market developments.

\section{The Case for Flexible Rates}

Much of the earlier support for flexible rates was based on the weakness of the pegged rate system, and Milton Friedman's classic article published in 1953 promised only modest benefits from the adoption of flexible rates. In the main, flexible rates were expected to isolate a country from monetary disturbances originating abroad and to help reconcile countries' divergent rates of monetary growth. It was also expected that flexible rates would lead to a smooth working of the external adjustment process without exchange crises or the need for controls on trade and capital flows. Many of those who supported flexible rates in the 1960 s, however, expected much more from them. They believed, in particular, that there was a longterm trade-off between employment and inflation, and saw exchange rate flexibility as an opportunity for individual countries to adopt price-employment objectives of their own choosing. It was also widely held that flexible rates would help to achieve stable growth, in particular by providing a significant measure of insulation from external real as well as monetary shocks. In the event, the flexible exchange rate system has not accomplished 
all that its supporters had hoped, and we consider each of the areas in which developments have turned out somewhat differently than expected. A. Flexible Rates and the Trade-off

The case for exchange rate flexibility was initially built on a belief that various countries cannot for long maintain the same inflation rate because of the undesirable but unavoidable tendency for governments to "tamper" with their currencies to various degrees. This was clearly the view advanced by Friedman (1953):

Governments of "advanced" nations are no longer willing to submit themselves to the harsh discipline of the gold standard involving rigid exchange rates. They will evade its discipline by direct controls over trade if that will suffice and will change exchange rates before they will surrender control over domestic monetary policy. Perhaps a few modern inflations will establish a climate in which, such behavior does not qualify as "advanced"; in the meantime we had best recognize the necessity of allowing exchange rates to adjust to internal policies rather than the reverse. ( $p .180)$

Differential inflation rates must inevitably lead to exchange rate adjustments, and flexible exchange rates were seen to provide the least inconvenient form of adjustment. Flexible rates were not viewed as the "first best" system, but only as a "second best" system that had to be used because political realities made the fixed rate system unworkable.

This argument based on political realism was soon, however, to be accompanied by the view that it would be desirable for countries to be left free to choose their own inflation rates because there is a long-term trade-off between inflation and unemployment. The choice of the inflation rate came to be seen as an important prerogative of a government, and flexible exchange rates were going to make it possible for each country 
to maintain its optimal inflation rate. This view was apparent, for example, in Johnson (1969):

On the one hand, a great rift exists between nations like the United Kingdom and the United States, which are anxious to maintain high levels of employment and are prepared to pay a price for it in terms of domestic inflation, and other nations, notably the West German Federal Republic, which are strongly adverse to inflation. Under the present fixed-exchange-rate system, these nations are pitched against each other in a battle over the rate of inflation that is to prevail in the world economy... . Flexible rates would allow each country to pursue the mixture of unemployment and price trend objectives it prefers, consistent with international equilibrium, equilibrium being secured by appreciation of the currencies of "price stability" countries relative to the currencies of "full employment" countries. (p. 100)

The notion that countries were faced with a trade-off between inflation and unemployment enjoyed a considerable vogue during the 1960 s following Phillips' article in 1958. A case can be made that the notion that there was any significant long-run trade-off between inflation and unemployment was never consistent with well-established generalizations about economic behavior. This is indicated by the low-key way in which the original basic criticism of the trade-off was made. Milton Friedman's initial critique of the long-term trade-off was made as part of a comment on a paper by Robert Solow. As Friedman (1966) put it in a very matter-of-

fact fashion:

The basic fallacy is to suppose that there is a trade-off between inflation and employment; that is to suppose that by inflating more over any long period of time, you can have on the average a lower level of unemployment ... . By speeding up the rate of monetary expansion and aggregate demand you can unquestionably increase output and employment temporarily ... only until people adjust their anticipations ... from a logical point of view, the true trade-off is between unemployment today and unemployment at a later date. It is not between unemployment and inflation. There is no longrun stable trade-off between inflation and unemployment. (pp. 58-59.) 
Similarly, when Phelps (1972) looked back at his critical analysis of the long-run trade-off argument he drew attention in a footnote to the fact that Professors Fellner and Wallich had put forward similar views at Yale prior to the discovery of the Phillips curve, and such reasoning could be found in the writings of Von Mises in the 1920 s and between the lines of the work of the classical economists.

It is nevertheless easy to see how the trade-off concept caught on among economists and policymakers. In the first place, it was really a codification of experience rather than a new idea. In the past, it had generally been true that periods of recession or depression had been characterized by reduced wage and price increases, and in the extreme case by absolute declines. Similarly, periods of prosperity had usually been associated with higher than average wage and price increases. It was not surprising, therefore, that plotting wage increases on the vertical axis and unemployment on the horizontal axis led to a cluster of points that suggested a curve that was downward sloping to the right. Second, there appeared to be ample evidence that economies react in this way in the short run, with the rate of wage increase declining under conditions of less than full employment and tending to rise during periods of boom. It was only one step from this to the view that a stable Phillips curve could be combined with a preference function for a particular society to derive an optimum choice of unemployment and inflation for an economy. Since it was assumed that every economy had its own unique Phillips curve and its own unique set of preferences for inflation and unemployment, it was not to be expected that countries would choose the same level of wage and price increases. 
As indicated above, the final stage in which the Phillips curve was used to choose a particular combination of unemployment and inflation over the long run is the one which might give pause; and it is certainly true that few were prepared to make this step without qualifications. Some, for example, recognized that after a time wage earners would start building expected future price increases into their wage bargains and that any particular trade-off would not be stable. It was argued, however, that it would take time for wage earners to adjust to rising prices, and that employment gains could be made today at the expense of higher inflation and unemployment at some later stage. This kind of "après nous le déluge" thinking served temporarily to maintain a rearguard action, but with the surge of inflation in the late 1960 s it became impossible to ignore the "not-so-long-run" inflationary effects of trying to raise employment permanently by using expansionary monetary or fiscal policies. There would thus be few today who would argue for flexible exchange rates on the grounds that they give countries a significant amount of freedom over the long run to choose a higher level of employment at the expense of more rapid price increases. The case for flexible rates as a first best system on these grounds can be dismissed. As will be argued later on in this paper, the more prosaic case based on political realities cannot be dismissed as easily. B. Flexible Rates and External Adjustment

Flexible rates were also expected to facilitate greatly the working of the international adjustment process, in particular among industrial countries. In the longer run, they would ensure that, at any given level of economic activity, the supply of and demand for foreign exchange originating 
from current account transactions would be consistent with the foreign investment flows that reflect longer-run differences in propensities to save and in investment opportunities among countries. In the short run, flexible rates would ensure that financing flows would be available to offset any short-run excess demand for, or supply of, foreign exchange originating from current account transactions and longer-run foreign investment flows without unduly large variations in the exchange rate. Demand-management policies would thus be free from external constraints. Many of the advocates of flexible rates were, of course, careful to point out that flexible rates were not an instant cure for all external adjustment problems. They recognized that, in particular, protracted imbalances inherited from the fixed rate period could not be eliminated overnight. More generally, they realized that trade flows would adjust to exchange rate changes only after a certain lag. It was also appreciated that, where underlying economic conditions were unstable, private capital flows might be insufficient to prevent some exchange rate overshooting while adjustments in the goods market were taking place. On the whole, however, flexible rates were expected to prevent the recurrence of the protracted external maladjustments experienced in the 1960s and early 1970s, and to eliminate gradually the imbalances inherited from the past at little cost in terms of exchange rate stability.

To a large extent, these expectations have not been realized. To begin with, the adjustment process in the goods market has not worked well. In particular, the Federal Republic of Germany, Japan, and Switzerland have maintained very strong current account positions despite the appreciation of 
their currencies both before and after the establishment of flexible rates. The total current account surplus of these three countries increased from about $\$ 8$ billion in 1972 to $\$ 31$ billion in 1978 . On the other side, the United States has kept experiencing recurring current account deficits despite the marked effective depreciation of the U.S. dollar that took place during that period. There is, of course, no reason to expect all industrial countries to have the same balance of payments structure, since there may be long-run differences among countries in propensities to save and in opportunities for investment. What is required for payments equilibrium, however, is that capital flows should also adjust to differing savings and investment propensities. It has been noted that existing financial conditions in the major surplus countries, Japan and the Federal Republic of Germany, are not well-suited for channeling savings abroad on a regular basis. (See Kindleberger (1976) for the Federal Republic of Germany, and McKinnon (1978) for Japan.) In the present case the fact that this pattern of current account balances is not an equilibrium one is apparent from the pressures on exchange markets that it generates. $\underline{1}^{\prime}$

The difficulties with the adjustment process in the goods markets are also apparent from the resurgence of trade restrictions (see International Monetary Fund (1978)). The argument that flexible rates would remove the balance of payments motive for restrictions on international trade has clearly not been validated. Countries do not seem to be prepared to accept Friedman's view that "if you have a flexible rate and you reduce

1/ Artus (1979) contains a detailed discussion of this issue. 
tariffs, movements in the exchange rate will automatically protect you against having any adverse balance-of-payments effects, and therefore you are not exporting or importing unemployment." (1969, p. 118.) Instead, there has been a tendency toward protectionism on current transactions. The persistence of the same pattern of current account imbalances eight years after the currency realignment of 1971 and six years after the widespread adoption of flexible rates cannot be blamed on any failure of exchange rates to move. Over a number of years, rates have changed in the right direction and by large amounts. It is of course easy to point out that either the current balances or the private capital flows would have had to adjust if the authorities had not intervened in the foreign exchange markets. This, however, is begging the question. The authorities intervened because current account imbalances were putting excessive strains on exchange markets. It is these strains that must be explained.

A first source of strains is that economic developments in the 1970 s had the unfortunate effect of increasing existing current account imbalances (see Artus (1979)). A marked reduction of the long-run rates of growth in the three surplus countries, namely, the Federal Republic of Germany, Japan, and Switzerland, was accompanied by a fall in domestic investment relative to saving.1/ At the same time, the main deficit country, the United States, was faced by a gradual fall in its production of natural gas and crude petroleum which led to a sharp increase in its dependence on imports of energy. The position of U.S. manufacturers in their own domestic markets minus domestic absorption, or to domestic saving minus domestic investment. 
was also eroded by the continuous growth of Japanese exports and the emergence of countries such as Hong Kong, North Korea, The Republic of China, and Singapore as major exporters.

These developments, however, do not explain fully the failure of the adjustment process to work more effectively over the past few years. Another reason seems to be that not enough consideration was given to the requirements for a successful adjustment through exchange rate changes. It has been known since the development of the absorption approach in the late 1940s $1 /$ and the rediscovery of the monetary approach by Polak (1957), Johnson (1957), and others, that current balances can be changed only if domestic absorption is changed relative to output, and that changes in exchange rates are not likely to have much lasting effect on this ratio via relative-price effects or otherwise if the monetary authorities are willing to validate any incipient price changes brought about by exchange rate changes. In particular, if a country is running a large deficit on its current account and wishes to alter this situation, it will have to cut its absorption through the use of a more restrictive monetary and fiscal policy unless it has spare capacity available.

A restrictive policy alone, however, may contribute only to an extended period of unemployment and an extremely slow adjustment in the relative prices between home goods and foreign goods $2 /$ because of the downward

\footnotetext{
1/ For a review of the development of the absorption approach, see Rhomberg and Heller (1977).

2/ The argument presented here in terms of home goods and foreign goods needs to be modified when the elasticity of substitution between internationally tradable goods produced by the various countries is extremely high. In such a case, the argument must be developed to some extent in terms of internationally tradable goods versus nontradable goods.
} 
inflexibility of goods and factor prices that may prevall in the short and medium run. The advantage of an accompanying exchange rate devaluation is that it changes relative prices directly. If the changes in relative prices are sustained and the foreign trade price elasticities are significant, the decrease in the real domestic demand for goods in general may be offset by a switch in foreign and domestic demands toward domestic goods so that there is no fall in the level of output.

In brief, flexible rates can play a useful role only if three interdependent conditions are met: (1) there is a supporting demand-management policy, (2) changes in the relative prices between home goods and foreign goods are sustained, and (3) a shift in relative prices leads to a switch in domestic and foreign demand between foreign goods and home goods.

The first condition for effective adjustment through exchange rates was not often present during the past five years. Flexible rates did not work better in part because demand-management policies were not usually directed toward adjustment of current account imbalances. $1 /$ Cutting the inflation rate, even at the cost of sluggish domestic aggregate demand, was the major policy target in the surplus countries, while the United States placed a higher priority on reducing unemployment in the short run. After maintaining restrictive policies through 1974 , the United States reversed course in 1975-76 and allowed a sustained expansion of domestic demand to develop accompanied by a rising inflation rate. The Federal Republic of Germany, Japan, and Switzerland, by contrast, relaxed their restrictive

1/ For a detailed analysis of the policy choices made by the United States, the Federal Republic of Germany, France, the United Kingdom, and Sweden during 1972-75, see B1ack (1977). 
policies more gradually. The shift toward a policy stance that was more consistent with the longer-run need for external adjustment took place only in the course of 1978, when the surplus countries expanded rapidly their money supplies and the United States moved to a more restrictive monetary policy. $1 /$

To some extent, domestic absorption may in fact have been left in certain cases to respond perversely, via the investment effect, to the change in the exchange rate. Mckinnon (1978), in particular, has focused. attention on this aspect of the exchange rate mechanism. Countries with a depreciating currency tend to experience an increase in the profitability of producing internationally tradable goods, at least initially, because prices in local currency increase more rapidly than the money wage rate. This leads to an increase in investment, in domestic absorption, and in imports. Opposite effects occur in countries with an appreciating currency. These effects should subside in the long run if the money stock remains unchanged, but, in the meantime, they delay the adjustment process. These effects can, however, easily be exaggerated. There is no doubt that in the surplus countries in the past few years the main causal nexus was, with lags at each step, from restrictive domestic policies to sluggish levels of economic activity, to large current account surpluses, and to exchange rate appreciations, rather than in the opposite direction.

The lack of supporting demand-management policies was not the only problem. A change in the price ratio between home goods and foreign goods

\footnotetext{
1/ It is worth noting that in the case of the three countries that shifted to supporting demand-management policies in 1976, the external adjustment worked relatively well during 1977-78. In France and Italy, however, the imbalances were not really deep-rooted, and in the United Kingdom North Sea oil played a major role.
} 
that persists implies a sustained change in the real wage rate. In the period of high inflation that has prevailed since the early 1970s, money illusion and wage adjustment lags have been reduced and, with explicit and implicit wage indexation clauses widespread in labor contracts, an adjustment of real wages is difficult to bring about. Johnson (1969) and others argued that, under a flexible exchange rate system, exchange rate adjustments would occur gradually, and their impact on the cost of living might remain unnoticed. 1/ The integration of the world economy has now proceeded so far, however, that the residents of few, if any, countries have the illusion that the local currency price of imported goods is not a major determinant of the cost of living. In fact, they may be particularly sensitive to exchange rateinduced domestic price changes. Exchange rate changes may thus fail to have a lasting effect on the real wage rate even if the initial impact is to move it back to its equilibrium level. Labor resistance, at least in the case of a depreciation, may gradually move it back to its initial disequilibrium position.

This "vicious circle" mechanism has been heavily focused upon by the critics of flexible rates; see, for example, the Rapport des Economistes Belges de Langue Francaise (1976). This effect should not, however, be exaggerated. First, the lags involved in the adjustment of the money wage rate to the consumer price index have not been eliminated. Second, and more important, the adjustment of the money wage rates to the consumer price

1/ As Kindleberger humorously put it, it is only banana republics that get excepted by Johnson from flexible rates on the ground that "they do not have the illusion that the price of bananas in local money is a major determinant of the cost of living, as contrasted with the price of imported goods." (Rindleberger, 1969, p. 5.) 
index is not beyond the power of the authorities to alter. This will be discussed in Part II. What is striking, in fact, in Chart 1 is the size and persistence of the effective changes in relative labor costs and goods prices brought about by the exchange rate changes, at least as far as the major industrial countries are concerned. $1 / 2 /$

A further disappointment as far as flexible rates and the adjustment process is concerned has been the slow speed of adjustment to changes in relative costs and prices in the goods markets. The extreme case is provided by Switzerland, where exports were still rising in 1978 in volume terms despite the 30 to 50 per cent loss in cost and price competitiveness experienced during the previous five years. Swiss exporters are highly specialized and do not have in many cases the possibility of shifting their production to the domestic market. $3 /$ Instead, they have shifted the composition of their export sales toward highly technical products and luxury goods with low price elasticities. The adjustment is certainly easier in larger and more diversified economies, but even in such cases it remains

1/ Not surprisingly, Chart 1 shows also that changes in relative export prices tend to be smaller than changes in relative deflators of value added which are themselves smaller than changes in relative unit labor costs. Part of the lack of change in relative export prices is a purely mechanical reflection of common cost elements (e.g., internationally traded raw material inputs) in relative export prices, but it is certain that the evidence also indicates that part of the exchange rate effect works through changes in profit margins and supply incentives. Aggregate indices could be misleading, but careful studies on specific types of manufactured goods by Kravis and Lipsey (1977) and Kravis et. al. (1977) confirm these findings.

2/ Wholesale prices for manufactures are proxied in Chart 1 by the deflator of the GDP originating in manufacturing because of the poor quality of a number of national indices for wholesale prices of manufactures (e.g., the French, Belgian, and Italian indices), which put an unduly low weight on finished products.

3/ The weakness of aggregate demand in the Swiss market has also prevented any major shift from export markets to the domestic market. 
CHART 1

EFFECTIVE EXCHANGE RATES, RELATIVES COSTS AND PRICES, 1969-78

-.-.- Effective exchange rate - Relative normalized unit labor costs in manufacturing

$\begin{array}{lr}\text { - Relative value added } & --- \\ \text { deflators in manufacturing } & \text { Ralues of manufactures }\end{array}$

(Quarterly indices, first half $1973=100$ )'
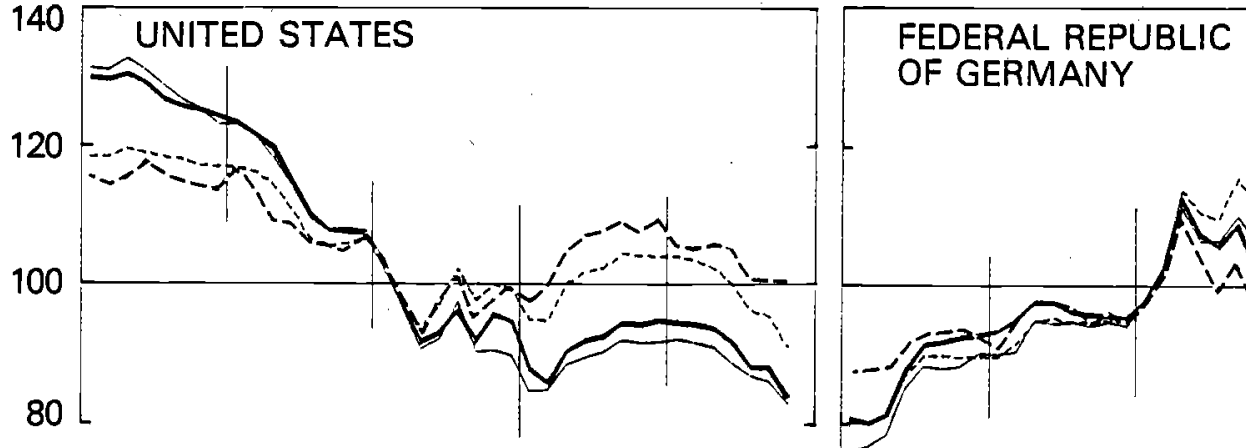

FEDERAL REPUBLIC OF GERMANY
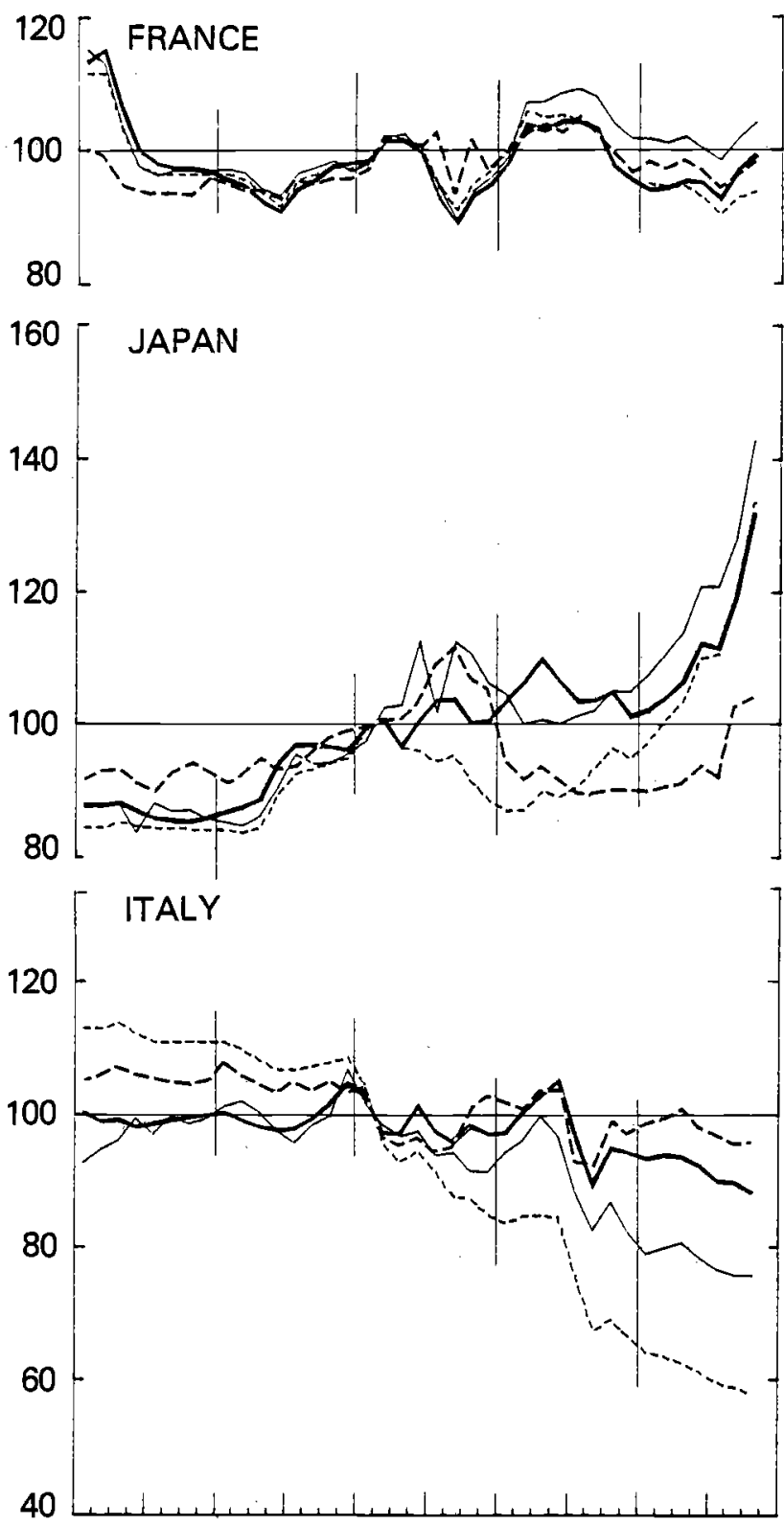
$\begin{array}{llllllllll}1969 & 1970 & 1971 & 1972 & 1973 & 1974 & 1975 & 1976 & 1977 & 1978\end{array}$
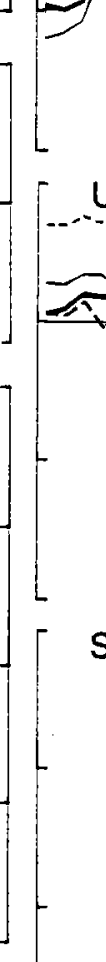

[ UNITED KINGDOM
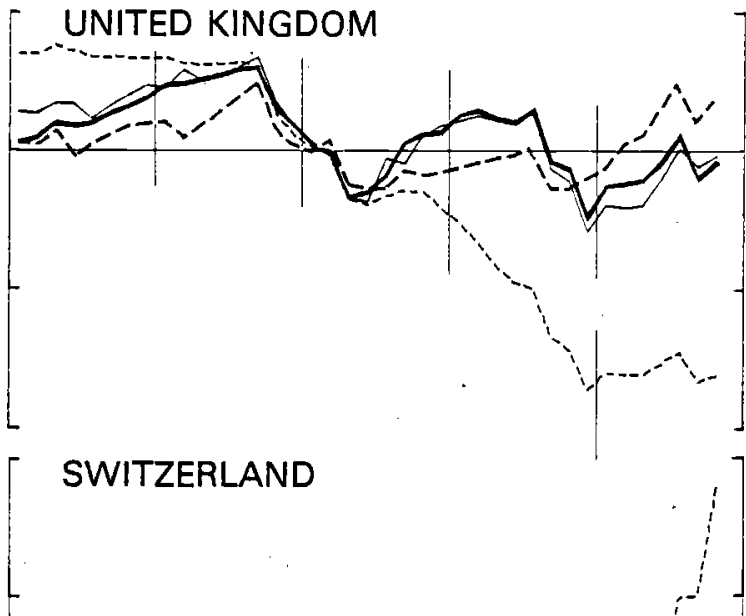
a lengthy process. It is very common to point out that, in order to become established or to expand in a new market, it is important to develop a distribution network, parts and service suppliers, and a reputation for reliability and quality. During the 1960s German, Japanese, and Swiss manufacturers supplied high quality goods at very competitive prices, and developed entrenched market positions in a number of products. In the process, these countries became strongly export oriented. Such a process cannot be reversed rapidly.

This is not to say that foreign trade flows do not respond in time to variations in relative prices. General economic reasoning and the historical evidence is convincing on this point, and the bulk of the econometric results point in the same direction. $1 /$ Stern et al. (1976), after reviewing more than 130 studies on price elasticities in international trade, conclude that "typical" long-run demand elasticities vary between -0.50 and -1.50 for total imports and -0.50 and -2.00 for total exports. The studies reviewed are based on data on the 1950 s and 1960 s. The estimates may be somewhat too high for the 1970s if, as McKinnon (1978) argues, a floating rate regime increases exchange rate uncertainties and weakens the incentives of traders to respond to cost and price differentials among countries. Estimates based on more recent studies tend to show, however, that while the long-run price elasticities may be smaller now, they remain substantial. Estimates from the IMF World Trade Model that are derived

$1 /$ It ought not be necessary for the economics profession to repeat the unf $\bar{f}$ ortunate experience of the early postwar period, when the notion of a dollar shortage was developed despite the difficulty of reconciling such a result with economic theory and economic history. "Prices don't matter" is a proposition on about the same plane as "money doesn't matter." 
from data that cover the period through 1977, for example, suggest a range of -0.50 to -1.00 for total imports and -0.50 to -1.50 for total exports (see Table 1).

Econometric estimates of the time lags involved in price effects range widely in the literature from no lag to a mean lag of three or four years. The most persuasive studies tend to find a mean lag of a couple of years; see, for example, Beenstock and Minford (1977). Oyer the first few quarters, the volume effects of an unanticipated change in the exchange rate is bound to be small, if only because of the long lags between orders and deliveries. In the IMF World Trade Model, for example, the sum of the elasticities of demand for imports and exports is smaller than unity for nine of the fourteen industrial countries over the first year and a half (see Table 1). With the perverse effects of an exchange rate change on the terms of trade that prevail over that period (Spitaeller (1979)), the result is the well-known " $J$ " curve effect. Initially, the trade balance worsens with an exchange rate depreciation and improves with an appreciation. This kind of lag no doubt explains why countries are often tempted to use more direct tools such as trade controls despite their welfare costs.

\section{Flexible Rates and Stable Growth}

Another major argument for flexible rates was that they would make it possible for national authorities to achieve more stable rates of economic growth. The argument was based on three propositions: (1) flexible rates, insulate a country's level of economic activity from foreign expansion and contraction; (2) flexible rates increase the degree of control of the 


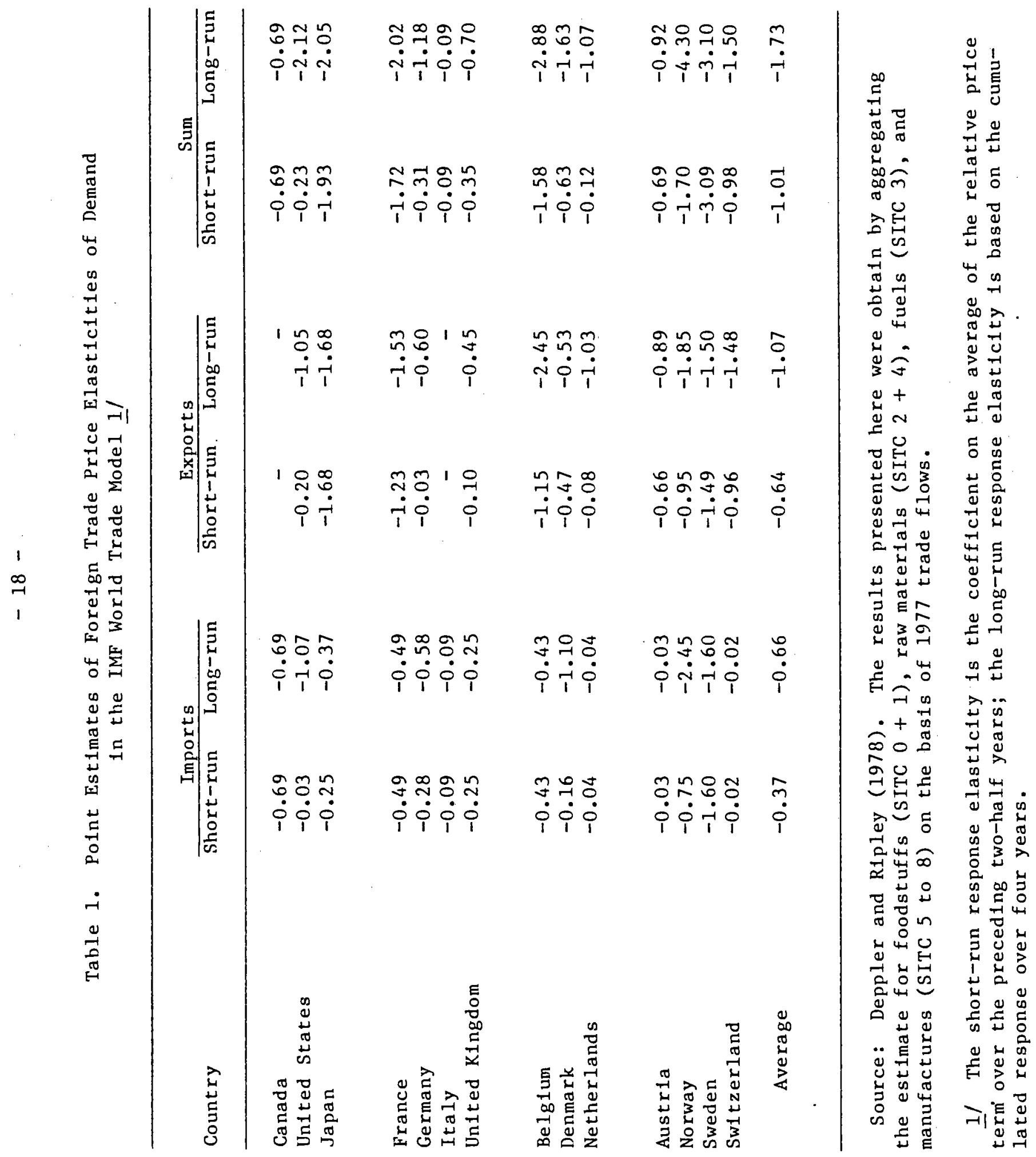


authorities over the money supply and allow them to use both monetary and fiscal policy to influence the level of economic activity without constraint from the external balance; and (3) the efficacy of monetary policy is greatly enhanced by flexible rates, i.e., the effect of a given change in the money supply on the level of economic activity is larger under flexible rates.

The events of recent years suggest that a.11 three of these propositions are questionable. The degree of economic interdependence seems to have been, if anything, greater since 1973 than before, in particular among European countries, whether in the "snake" or not. Similarly, there has been no sign either of greater economic stability brought about by an increase in the control of the authorities over the money supply, or much evidence of an increase in the efficacy of such policies.

The conclusion of greater insulation from variations in economic activity abroad under flexible rates is based on two assumptions: (1) a real external disturbance leads to an exchange rate change; and (2) the exchange rate change prevents the external disturbance from having an effect on the domestic economy. $1 /$ The effect of a fall in foreign demand, for example, is seen to lead to a depreciation of the exchange rate rather than to a deterioration of the trade balance that would have a deflationary effect

I/ The insulation issue is discussed here to a large extent from a singlecountry rather than a global point of view. Taking into account the likelihood that disturbances of various kinds may tend to affect the various countries at the same time leads to extremely complicated theoretical models which do not add much to the understanding of the basic issues involved, since there is no reason to assume stable patterns of covariances among these disturbances. 
on the domestic economy. These two assumptions, however, seem to be valid only to a limited extent.

Whether an external disturbance leads to an exchange rate change will depend in part on whether the disturbance is viewed as being temporary. In the case of a temporary disturbance, capital flows may have a stabilizing influence on the exchange rate as market participants maintain their views on the longer-term equilibrium value of the exchange rate. When the background is stable and there is a belief in a "normal" exchange rate, as during much of the period in which the Canadian dollar floated in the 1950s, offsetting effects of this kind have been found. Indeed, it is possible to envisage capital flows playing an even more active role. If the fall in foreign demand results from a recession abroad accompanied by a decrease in the rate of return on investment, capital may tend to move to the home country where the level of economic activity is sustained and the interest rates are higher. Modigliani and Askari (1973) argue that this factor may more than offset the effect of the worsening of the trade balance so that the exchange rate appreciates rather than depreciates. 1 / In this case, flexible rates would increase the impact of foreign disturbances on domestic economic activity.

In the discussion of the external adjustment process, however, it was noted that capital flows had not offset completely the effects of demandinduced disturbances on the current account in recent years. As pointed evidence confirming that hypothesis for the specific case of Canada during the 1950 s can be found in Rhomberg (1964). 
out in that discussion, the key factor in the failure of the exchange rate to provide insulation is the lag in the response of trade flows to changes in relative prices.

All the major econometric models of world trade--including the Link model presented in Ball (1973) and the IMF World Trade Model described in Deppler and Ripley (1977)--show conclusively that year-to-year changes in the volume of imports and exports are dominated by variations in real aggregate demand. During the first one or two years, offsetting effects that may result from exchange-rate-induced variations in relative prices are generally only a small fraction of the effects of demand changes. Even over a longer period, e.g., three years, the effect of demand changes remains large relative to the offsetting effects of exchange rate changes. Some calculations of the magnitudes of the fall in exchange rates necessary to offset increases in demand for 14 industrial countries based on the IMF World Trade Model were included in the 1978 IMF Annual Report. The results indicate that an increase of 1 per cent in manufacturing output maintained for three years has a strong negative effect on the trade balance in all 14 countries, ranging from $11 / 2$ to $31 / 3$ per cent of 1977 trade flows. It was estimated by comparison that in most cases exchange rate declines of the order of 5 to 15 per cent would be necessary to produce the same trade balance effects.

There are thus strong grounds for concluding that a flexible rate does not provide an automatic mechanism that will insulate a country's level of 
economic activity from foreign expansion and contraction. $1 / 2 /$ If a flexible rate contributes to a more stable rate of growth, it would be because it frees the authorities from any balance of payments constraint and allows them to direct demand-management policies toward the achievement of domestic stability, or because it increases the degree of control of the authorities over the money supply and enhances the efficacy of demand-management policies. $3 /$.

That flexible rates allow the authorities to control the money supply (or more precisely, the monetary base) was, until recently, considered a truism; and indeed it is, if the flexible rate regime is one where the monetary authorities never worry about exchange rate developments in forming their monetary policy. It has become obvious in recent years, however, that such a benign neglect policy may lead in many cases to exchange rate instability. Artus (1976) and Dornbusch (1977), among others, have focused attention on the high elasticity of the exchange rate with respect to (unanticipated) changes in the money supply. While there is some difficulty in explaining this high elasticity (a further discussion of this issue is given later), the evidence is clear that uncoordinated monetary policy changes

\footnotetext{
I/ It similarly follows that real disturbances originating at home will tend to be transmitted abroad in large measure under flexible rates, and thus their effects on the home economy will be diffused.

$2 /$ This conclusion is also verified by empirical studies (e.g., Ripley $(1 \overline{9} 79)$ ) which seem to suggest that the international transmission of fluctuations in economic activity is no less powerful under flexible rates than under fixed rates.

$3 /$ In recent years the insulation argument has been seen to depend more and more on the ability of the authorities to use policy instruments for reaching domestic targets without being constrained by the external balance rather than as a purely automatic mechanism. See, for exampie, Tower and Willett (1976).
} 
among countries often tend to lead to large changes in exchange rates. Even if the money supply is kept stable in the various countries, exchange rate instability may be a problem because of the short-run instability of the demand for money.

These considerations do not, of course, detract from the fact that flexible rates allow the authorities to maintain, in the longer run, a monetary growth that is consistent with their ability to keep a low inflation rate. They do, however, indicate the consequences that can follow from attempts to use monetary policy to affect the level of economic activity over the short run without regard to the effects on the exchange rate. The argument that flexible rates enhance the efficacy of demandmanagement policies, in particular monetary policies, has also turned out to be somewhat deceptive. The argument is similar to the one presented for insulation. It was derived from the observation that the change in money supply is likely to be accompanied by a variation in the exchange rate that would reinforce its effect. As discussed above, however, the response of the volume of the foreign trade flows to a change in the exchange rate is likely to be so small in the short run that the additional expansionary effect would not be noticeable. A further weakness in the efficacy argument is that price increases caused by the exchange rate depreciation may sharply reduce the expansionary effect of the increase in the money supply. Monetary policies affect the level of economic activity only if prices in the goods markets adjust slowly to a monetary change. By speeding up the price adjustment, flexible rates reduce the efficacy of monetary policies. $1 /$

I/ It is mainly on the basis of this argument that many authors such as Argy (1975) have concluded that monetary policy will tend to have stronger price and weaker employment effects in the short run under flexible rates. 
The efficacy argument is also to some extent misleading. The magnitude of the effect of a given policy change is important, but it is even more important that the effect of that policy change be foreseeable. There is not much reason to believe, unhappily, that flexible rates increase the extent to which the authorities can reliably estimate the quantitative effect of a certain discretionary change in monetary policies. This effect will depend to a large extent on the behavior of the exchange rate and the magnitude and timing of the effects of exchange rate changes on prices and on the level of economic activity in the short run. In this area, it is particularly difficult to make reasonably accurate forecasts.

\section{The Case Against Flexible Rates}

If the advantages of flexible rates have fallen short of the expectations of their advocates, it must also be recognized that their drawbacks have been less damaging than was anticipated by their detractors. The word "drawback" may not even be appropriate to characterize the disasters that some suggested would occur if flexible rates were adopted. It was argued-for example, by Roosa (1967)--that, as a practical matter, a system of flexible rates was not workable. As he put it:

I have never met anyone who has attained the competence of a seasoned trader who would be prepared to continue in the business if, by some sleight of hand, all parities were to be abandoned and the central banks were barred from entering the markets in their own currencies. Many, and I include myself, would probably want to withdraw from trading activities even under the sort of flexible-rate system in which the central banks were allowed a role, so long as there were no parity guidelines to get us into the right ball park. (p. 52.) 
These fears were rapidly discarded as experience was gained with the new system. Three other traditional arguments against flexible rates have, however, shown more staying power, but only in a milder form than initially advanced. The first is that flexible rates are inherently unstable; the second, that exchange rate uncertainties disrupt domestic and international economic relations; and the third, that flexible rates promote faster inflation.

\section{A. Exchange Rate Instability}

Advocates of flexible rates had suggested that exchange rates would reflect "underlying economic conditions"; as long as these conditions were stable, exchange rates would also be stable. The underlying economic conditions in question were not precisely defined, but the impression was left that exchange rates would move only to the extent necessary to offset differential rates of inflation and to compensate for changes in real factors, such as tastes and production techniques, that usually take place only gradually. These views, however, never seemed to prevail completely over the argument that flexible rates would be unstable and would disrupt domestic and international economic relations.

After six years of flexible rates, a good deal of evidence has accumulated which indicated that flexible rates tend to be unstable in the commonsense meaning of "moving up and down a lot" from day to day, month to month, and year to year. Illustrations of that instability are given in Charts 2 , 3, and 4. Chart 2 shows the noon rates between the U.S. dollar and the currencies of the major industrial countries and Switzerland, while Charts 3 and 4 give the rates of change in these rates on a daily and quarterly basis, respectively. 
CHART 2

\section{EXCHANGE RATES IN TERMS OF U.S. CENTS, APRIL 1, 1973 - DECEMBER 31, 1978}

(Daily noon quotations in New York)
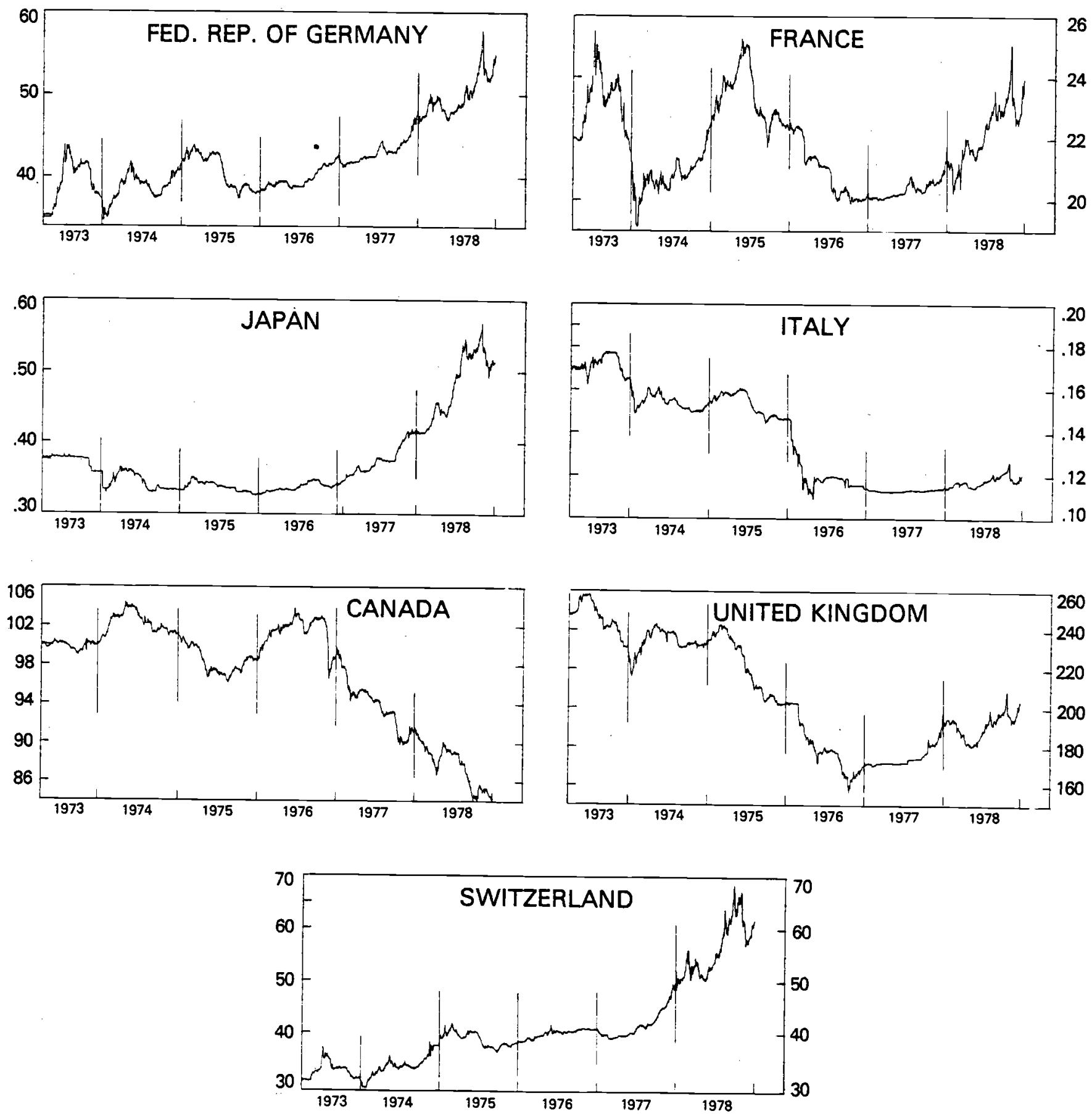
CHART 3

SHORT-RUN VARIABILITY IN EXCHANGE RATES IN TERMS OF U.S. DOLLARS, APRIL 2, 1973 - DECEMBER 31, 1978

(Daily percentage changes)
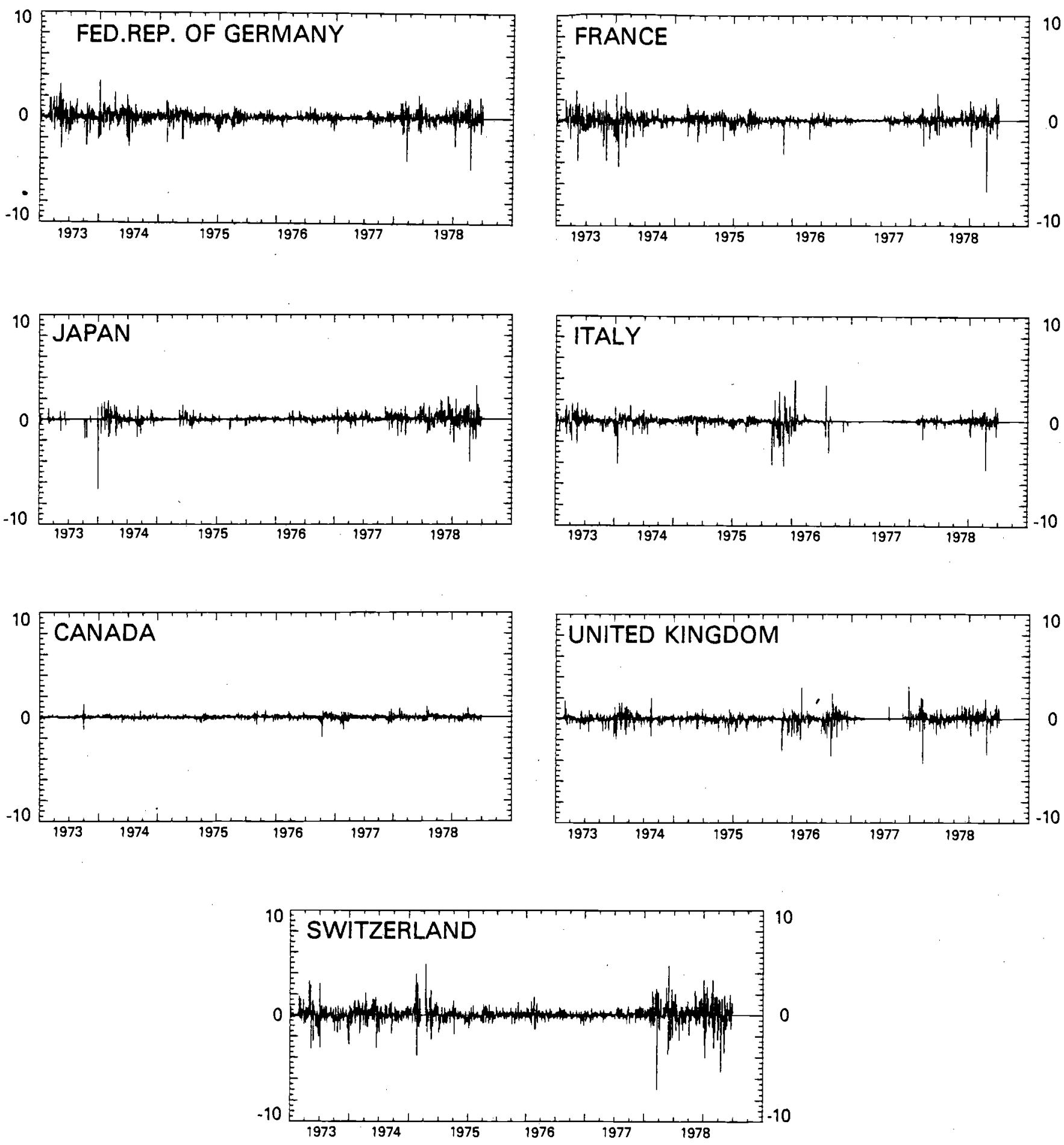
CHART 4

\section{SHORT-RUN VARIABILITY IN EXCHANGE RATES IN TERMS OF U.S. DOLLARS, APRIL 2, 1973 - DECEMBER 31, 1978}

(Quarterly percentage changes)
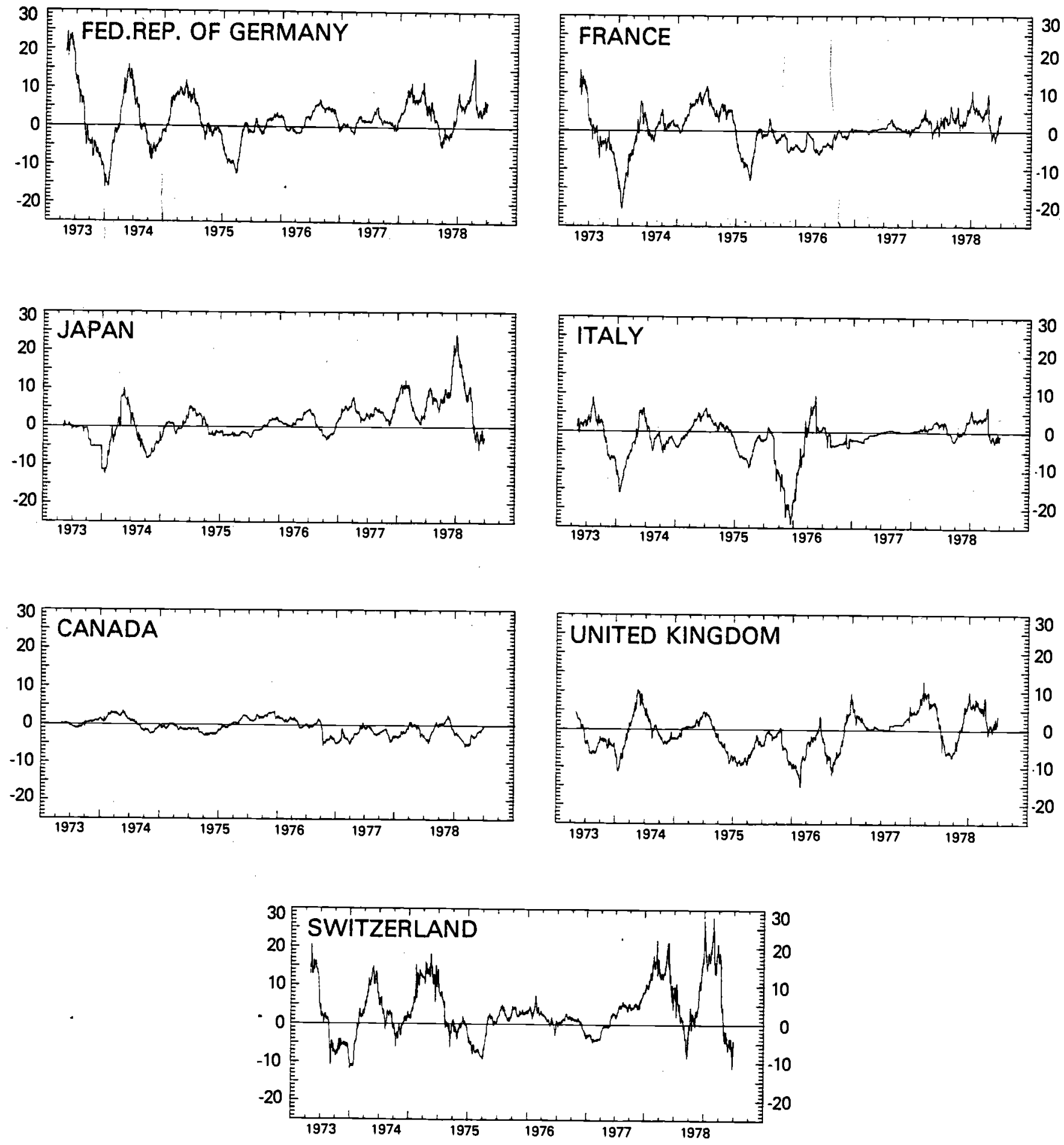
Much of the exchange rate instability shown in these graphs reflects the marked domestic and international instability of recent years, including the breakup of the par value system, the oil price increase of 1973, high and divergent inflation rates, and the worldwide recession followed by recoveries at varying rates among industrial countries. This being granted, there are also a number of developments that suggest that exchange markets with flexible rates may be characterized by the kind of instability generally found in other markets that are strongly influenced by expectations. The "cycles" in the U.S. dollar/deutsche mark rate in 1973-76 are the first development that attracted attention in that context. Then came ( 1 ) the sudden and extremely rapid depreciations of the lira, French franc, and pound sterling in 1976, followed in $1977-78$ by the recovery of these currencies, in particular the pound; (2) the appreciation, then sharp fall in the Canadian dollar in 1976-78; and (3) the rapid depreciation of the U.S. dollar against the deutsche mark, Swiss Franc, and yen in 1977-78, culminating in the October 1978 crisis. In all these cases, there seems to be the same lack of parallelism in the short run between the exchange rate change and the change in the underlying economic and financial conditions.1/

1/ The 26 and 34 per cent depreciations of the U.S. dollar against the deutsche mark and yen, respectively, from end-June 1977 to end-October 1978, in particular, were out of proportion with underlying developments at least in terms of either rates of monetary growth or inflation rate differentials.

Money (M1)

(Percentage change based on

\begin{tabular}{lrr}
\multicolumn{3}{c}{ period averages) } \\
\hline 1975 & $1976 \quad 1977$ & 1978 \\
\hline
\end{tabular}

Germany

Japan

United States

$\begin{array}{rrrr}14.1 & 10.2 & 8.3 & 13.8 \\ 10.3 & 14.2 & 7.0 & 10.8 \\ 4.5 & 5.1 & 7.2 & 8.3\end{array}$

GNP deflator

(Percentage change)

\begin{tabular}{llll}
\hline 1975 & 1976 & 1977 & 1978 \\
\hline
\end{tabular}

$\begin{array}{rrrr}6.7 & 3.3 & 3.6 & 3.5 \\ 12.8 & 5.5 & 5.4 & 3.7 \\ 9.6 & 5.2 & 5.9 & 7.2\end{array}$


Exchange rates were sticky for a certain period, then changed suddenly, overshot, and finally moved back to some extent, a pattern that is alien to the gradual adjustment expected by advocates of flexible rates.

In part, the stickiness of exchange rates reflected governmental intervention. This is clear for the lira, French franc, and pound sterling, where the authorities intervened in the foreign exchange market on a significant scale during 1974-75. More generally, the authorities concerned, with the exception of the U.S. authorities in 1977, did not encourage exchange rate adjustments during periods where the nominal exchange rate tended to be stable while the underlying economic and financial conditions were changing. They tended rather to reinforce the inertia of private market participants. In addition, however, reasons for the instability must be found in the nature of the exchange rate determination process. Nordhaus (1978) has argued that volatility is to be expected in an "auction market" such as the exchange market under floating rate simply because there are incessant surprises. As he puts it:

In those pure auction markets where prices are the main shockabsorber, considerable price volatility is the result. These conditions generally prevail in raw foods and commodities markets, in markets for many financial instruments such as common stocks, or when a regime of pure floating exchange rates exists. Such volatility is an intrinsic feature of real-world auction markets-markets in which there are incessant surprises due to weather, changes in taste, inventions, political upheaval, inflation, recession and boom, etc. (p. 7.) $1 /$

This auction market characteristic is important, but it certainly does not account fully for the magnitude of the observed short-run exchange 1/ In the same testimony before the Sub-Committee on Foreign Economic Policy, Nordhaus pointed out that the day-to-day variability of the Dow Jones industrial average in the recent period had been almost 0.5 per cent a day as compared with 0.1 and 0.2 for the nominal value of the U.S. dollar as measured by a trade-weighted index. 
rate movements. To understand why a large measure of instability may be an inherent characteristic of flexible rates it is useful to review recent developments in the analysis of exchange rate determination. The basis of this analysis is that exchange rates among currencies are the relative prices of these currencies and therefore sensitive to any change in the supply of, or demand for, financial assets denominated in these currencies. Indeed, at every point in time the exchange rate must be at such a level that the amount of financial assets denominated in a particular currency matches the amount that market participants desire to hold. This is not to say that relative prices in the goods markets do not influence exchange rates, but the adjustment process in the goods markets works so much more slowly than in the financial asset markets that they play a somewhat secondary role in the short run. $1 /$ The important contribution of this approach is that, by treating exchange rates as financial asset prices, it focuses attention on the strong influence of expectations. Thus it is not only the amount of assets available today that influences asset prices but also the amount expected to be available tomorrow. It is the instability of these expectations that appears to be a major factor in short-run exchange rate instability. 2

1/ Several variants of this "asset market" approach are presented in the papers included in the Scandinavian Journal of Economics No. 2, 1976, and discussed in Bilson (1979), Dornbusch and Krugman (1976), Schadler (1977), and Isard (1978).

2/ Here also the word unstable is used in its common-sense meaning of moving up and down frequently, rather than in the sense of moving continuously away from equilibrium once disturbed. 
It is easy to explain why the expectations of market participants tend to be unstable. Forecasting the future course of monetary and other management policies in different countries relative to each other is normally, at best, a matter of guess work. Mussa (1976), among others, has pointed out how tenuous the information that forms the base for such forecasts usually is, and how any new piece of information, even if somewhat unreliable, may lead to a substantial revision of exchange rate expectations and a sharp movement in the spot rate. I/ The instability of expectations is increased further if market participants have reason to believe that domestic price changes related to exchange rate variations may lead to accommodating changes in the money supply. Furthermore, the money supply is not the only element that affects the exchange rate so that even if the authorities gradually stabilize expectations with respect to monetary policies by respecting preannounced monetary policy targets, exchange rate expectations would not necessarily be stable.

All those elements are, of course, not new to the debate. The new element, however, is the realization that, once the authorities refuse to be limited to policies that will keep the exchange rate along a predetermined time path or at a certain parity, market participants will normally be quite uncertain as to the future path of the exchange rate even when underlying economic conditions are not markedly unstable. Thus, there seems every likelihood that flexible rates will continue to show some

1/ Countries may have monetary targets, but in practice such targets are not often respected for long and thus do not necessarily stabilize the expectations of market participants with respect to the future time paths of money
supplies. 
short-term instability in response to the inherent instability of market participants' expectations. Of course, the more unstable the underlying economic conditions are, the more unstable expectations will be.

The instability of expectations is not the only factor leading to exchange rate instability. Various institutional rigidities have also been focused upon in the context of the asset market approach to explain exchange rate instability. Mckinnon (1976) has pointed out that there might be an inadequate supply of private capital available for taking net positions in either the forward or spot markets on the basis of long-term exchange rate expectations. 1/ Thus, cyclical variations in the demand for foreign exchange originating from trade or financial activities that may be sustained for a number of years may lead to large exchange rate movements because of a lack of investors with both the funds and the willingness to take a longer-run open position. Branson (1976), Dornbusch (1976), and Kouri (1976) have rather focused on the slow speed of adjustment in the goods markets in cases of unexpected monetary policy changes to explain exchange rate instability. While their models differ, they all embody the hypothesis that asset markets are continuously in equilibrium while the goods markets adjust only gradually. They show that under such conditions, the immediate response of the exchange rate to a monetary policy change overshoots the new longer-run equilibrium rate. 2 /

1/ As Isard (1978) notes, the unwillingness of banks and multinational corporations to take open positions on the basis of longer-run exchange rate expectations is to some extent related to the imprecision of these expectations.

2/ For a review of these various models, see Bilson (1979), Schadler $(1 \overline{9} 77)$, and Isard (1978). 
This "monetarist" explanation of exchange rate movements should not obscure the fact that the inadequate current-balance adjustment discussed in Part $I$ is also one of the causes of exchange rate instability. $1 /$ The first reason is that a current account surplus leads to an accumulation of net foreign assets. This in turn may lead to an appreciating exchange rate to the extent that a fall in the relative price of foreign assets is needed as an incentive for domestic agents to increase the share of these assets in their portfolio. $\underline{2} /$ Probably more important, however, is the impact of current balance developments on exchange rate expectations. The emergence of a current account surplus that is not related to temporary distubances may, at times, be rightly interpreted as an indication that a rise in the real exchange rate is required if a lasting adjustment is to take place. $3 /$ How much of a change in the nominal rate will be necessary to bring about the needed adjustment is, however, the type of question that cannot be answered with any degree of certainty. Market participants will, therefore, continually reassess their views of the needed exchange rate change on the basis of actual current balance developments without always being able to discount properly the effects of temporary divergences in economic cycles, "J" curve effects of exchange rate changes, etc.

\footnotetext{
1/ It is somewhat astonishing in this context that most of the recent economic literature on exchange rate determination completely discarded this factor up to about 1978, at which time Dornbusch (1978) noted that: "The current account has just made it back as a determinant of exchange rates." (p. 1.)

2/ Some empirical evidence for this effect has been found by Artus (1976), Branson et al. (1977), and Porter (1977).

3/ At other times, the surplus on current account may be the result of factors that provide their own offset to the current account surplus in the form of capital flows.
} 
A further possible source of instability in the present system is related to the fact that several currencies are held by central banks as part of their international reserves. Any major action to change the composition of these reserves could lead to sharp exchange rate movements and disorderly market conditions. Because they are conscious of the possible harmful effects of their actions on the value of their portfolio and on the system as a whole, large reserve holders tend to avoid major portfolio shifts. As result, they may maintain larger stocks of certain reserve currencies than they would choose to have, and the possibility that some of these balances might come on the market creates uncertainty in the minds of both private and official holders. The overhang of official sterling balances seems to have played a destabilizing role through 1976. 1/ More recently, there have been signs that actual or potential diversification out of U.S. dollar reserve balances was a factor in the weak behavior of the U.S. dollar in 1978.

The inherent instability of expectations, limitations on the role of stabilizing capital movements, the slow speed of adjustment in the goods markets, the persistence of current account imbalances, and the existence of a multiple reserve currency system account for much of the volatility in exchange market behavior in recent years. $\underline{2}$ There are, moreover, cases

\footnotetext{
1/ In February 1977, a $\$ 3$ billion medium-term stand-by credit facility was extended to the Bank of England by a group of European central banks and the central banks of Canada, Japan, and the United States. This facility could only be drawn upon if U.K. official reserves stood at less than the equivalent of $\$ 6,750$ million, and it has not been used in the succeeding two years.

2/ Other factors of volatility have also been mentioned. In particular, Girton and Roper (1976) have focused on the substitution between the noninterest-bearing portions of different countries' money stock (cont'd)
} 
in which extrapolative expectations or "bandwagon" behavior on the part of market participants appears to have played a role. Dooley and Shaffer (1976) have found some tentative evidence indicating that such effects may occur, and it is hard to explain exchange market developments in October 1978 without reference to extrapolative expectations or bandwagon effects. Out of 22 market days in October, the U.S. dollar depreciated on 19 days against the deutsche mark, with the other 3 days characterized by relatively flat movements.

B. The Costs of Instability

While the evidence is building up to suggest that a floating rate system is characterized by a good deal of what is commonly regarded as exchange rate instability, it is not clear how important any detrimental effects of this instability have been or will prove to be. With forward rates of exchange seeming to contain little information on actual movements

2/ (cont'd from p. 32) that may occur when the expected rate of inflation, and therefore the expected rate of return on fiat money, differs among countries. Such portfolio shifts do not necessarily take place gradually over time and may be the cause of sudden exchange rate movements. Kareken and Wallace (1978) have even advanced the view that the choice between different fiat moneys is "of the all-or-nothing variety," so that in a floating rate system without stringent capital controls there is simply no equilibrium value for the exchange rate. There is little if any empirical support for the view when put in this extreme form. As Haberler (1979) notes, the uncertainty about future inflation rates and, of greater importance, the legal provisions, the extra cost of transactions of using different money, and the sheer inertia of the public, ensure the local dominance of national money, except under conditions of hyperinflation. In fact, even in the case of Germany in 1920-23, the substitution was slow. Under more normal circumstances, the substitution is quite limited as demonstrated by all available historical evidence. (See Brillembourg and Schadler (1979) for an attempt to use econometric techniques to estimate the substitution elasticities among major currencies.) It is perhaps worth adding that if a country wishes to discourage a flight from its noninterest-bearing money, it is possible to arrange to pay interest, even on currency. 
of spot rates into the future (see Cornell (1977)), this instability is probably accompanied by an increase in uncertainty. It is difficult, however, to assess the detrimental effects that may follow from the increase in uncertainty. These detrimental effects $1 /$ could include (1) a reduction foreign trade, (2) a decline in foreign investment, and (3) the adverse effects resulting from changes in the value of reserve currencies.

The risks of a dislocation of international economic relations was a major theme of the critics of a flexible rate system in the 1950 s and 1960 s. It was argued that exchange rate flexibility, by increasing the uncertainty associated with international transactions, would discourage both foreign trade and international investment.2/ The additional uncertainty associated with foreign trade could be related to the risk of exchange rate changes during the period between contract and settlement, or to the risk of changes in the relative cost and price competitiveness of countries because of exchange rate changes. Supporters of flexible rates argued that forward markets could be used to take care of the first type of risk, and that over the longer run exchange rate changes would reflect changes in price and cost competitiveness.

1/ For a previous discussion of a number of these detrimental effects, see Artus and Crockett (1978).

2/ In The Treatise on Money, Keynes differentiated between the effects of exchange rate fluctuations on foreign trade and foreign investment. On the first he commented: "So far as foreign trade is concerned, I think that the advantage of fixing the maximum fluctuations of the foreign exchanges within quite narrow limits is usually much over-estimated. It is, indeed, 1ittle more than a convenience."' ( $p .298$ ) On international investment his view was different: "When we come to foreign lending, however, the advantages of a fixed exchange rate must ... be estimated much higher. In this case the contracts between borrower and lender may cover a far longer period than would be contemplated by any practicable dealings in forward exchange." ( $p .298$. 
The experience of the last few years has indicated that some of the difficulties likely to be encountered by those engaging in international transactions were treated rather casually in the earlier debate. It might appear that a businessman has eliminated exchange risk if he covers the position with a forward transaction, but, if his competitor does not and is thereby able to offer goods at a lower price, the forward transaction does not eliminate all the consequences of a change in the spot rate. Further, little was said about the difficulties firms would encounter in avoiding. major fluctuations in their profit figures, and the problems that would be posed by their own internal accounting arrangements or externally applied accounting standards.

While life may have become more complicated for those engaged in international transactions, this does not necessarily mean that there has been a significant effect on foreign trade or investment. Indeed, to date, the statistical evidence tends to be negative. Hooper and Kohlhagen (1976) introduced various proxies for exchange rate uncertainty (variability) in import and export volume equations for the United States and the Federal Republic of Germany for 1965-75, and found they did not play any significant role. Various tests making use of the IMF World Trade Model (see Deppler and Ripley (1978) for the description of the model) have also failed to detect any systematic effects of exchange rate uncertainty on disaggregated trade flows for individual industrial countries through 1977 . The evaluation of the trade pattern of the snake countries is also interesting in this context. While the proportion of intra-snake manufacturing trade to non-snake trade expanded in the late 1960 s and early 1970s, 
it contracted slightly between 1972 and 1977 despite the increased stability of intra-snake exchange rates relative to exchange rates with nonsnake countries during that period. 1/ Such tests are not precise enough to reject the hypothesis that exchange rate instability has had harmful effects on foreign trade flows. But even taking into account the limitations of the data and the fact that there are likely to be long lags in the response of trade to exchange rate instability, these tests do raise doubts that major effects have been present.

Exchange rate instability did not have more of an effect on international trade in part because facilities for hedging have normally remained adequate. It is only in a few instances, such as the case of the lira in early 1976, that forward markets have dried up because of excessive uncertainty. 2/ The costs of hedging in such markets as measured by the bid-ask spreads have increased with the move to flexible rates, but they still represent only a minute fraction (usually about one tenth of a per cent or. less) of the value of a currency. Forward contracts for as long as a year are not unusual, and, at a price, a trader can always cover by borrowing in one market and lending in the other. In many cases, multinational corporations can hedge internally by matching the timing of their future receipts and disbursements in particular currencies. It remains difficult, 1/ The snake countries considered here are Belgium-Luxembourg, Denmark, the Federal Republic of Germany, the Netherlands, and Norway.

2/ Forward markets do not exist for the currencies of a number of deve1oping countries. Normally these currencies are, however, pegged on a major currency and the forward market for that currency can be used for hedging purposes. Those currencies that are pegged to a basket can achieve partial hedging by operating in the forward market for a major currency. 
however, to hedge against the risk that exchange rate movements that are sustained for, say, two to three years may temporarily change relative costs and prices in the goods markets.

It is even more difficult to assess the effects of exchange rate instability on the long-term investment flows which cannot be easily covered in forward markets or through other hedging mechanisms. So far little evidence has accumulated that financial and nonfinancial enterprises have significantly curtailed international capital movements in response to exchange rate fluctuations. To the extent that it is expected that changes in relative price levels and shifts in exchange rates will tend to be offsetting, some built-in safeguards are present, and the other major determinants of investment flows then tend to dominate decisions. These include, in the case of foreign direct investment, positive advantages in terms of direct access to material inputs, skilled labor, markets, etc. It is worth emphasizing, however, that even if exchange rates adjust to relative price and cost levels over the long run, instability in exchange rates and selective prices in the short run can have detrimental effects because in planning their investment strategy firms must put a relatively high weight on expected rates of return in the early years of a project. These rates of return are uncertain in situations of exchange rate instability.

Exchange rate instability involving a major reserve currency raises particular problems. For example, developments with respect to the U.S. dollar in 1978 had major repercussions throughout the system, as virtually every country found some of its important bilateral rates changing significantly. Moreover, with the bulk of official reserves held in the form 
of U.S. dollar balances, this meant major changes in the value of international reserves, and put pressure on reserve holders to consider diversifying their portfolios. The precipitous decline in the dollar relative to the deutsche mark and the yen generated a very pronounced reaction against the floating system. It may turn out retrospectively that this was a structural change that needed to take place and would have been difficult in the extreme to bring about without the contribution made by the relatively free play of market forces. The immediate effect, however, was to add to the disillusionment with the floating rate system.

These brief comments on the costs of exchange rate instability have touched upon the conventional quantifiable costs. While there are clearly some grounds for the kind of irritation that seems to have developed about the operation of the flexible rate system, the extent of the reaction is somewhat surprising. $1 /$ Why is it that it is rare these days to hear vigorous criticism of fluctuations in other financial markets, such as the equity or bond markets, and such strong feelings about exchange rate fluctuations? Complacency about stock market fluctuations was not always the general rule. Keynes' comments in the General Theory are well-known:

Speculators may do no harm as bubbles on a steady stream of enterprise. But the position is serious when enterprise becomes a bubble on a whirlpool of speculation. When the capital development of a country becomes a by-product of the activities of a casino, the job is likely to be ill-done. The measure of success attained by Wall Street, regarded as an institution of which the proper social purpose is to direct new investment into the most

\footnotetext{
1/ Surveys of U.S. entrepreneurs are reviewed in Burtle and Mooney $(1 \overline{9} 78)$. For a survey of U.K. entrepreneurs, see Oppenheimer (1978). U.K. businessmen seem to react more negatively than their U.S. counterparts to exchange rate instability.
} 
profitable channels in terms of future yield, cannot be claimed as one of the outstanding triumphs of laissez-faire capitalism--which is not surprising, if I am right in thinking that the best brains of Wall Street have been in fact directed towards a different object. 1/ (p. 159)

There is little echo of this view in current discussions of equity markets, but clearly a good deal of this kind of sentiment in discussions of exchange markets. There are, no doubt, many reasons for this, the most obvious being that any "cure" for equity market instability may be either impossible to find or worse than the disease. Decades of experience under the gold standard and under par values do not, however, suggest that stability in exchange rates is either impossible or necessarily hazardous to the effective operation of economies. Moreover, the ordinary public can escape direct involvement in equity markets, even if some of their resources are committed to these markets by their pension funds or insurance companies. The exchange rate, however, has very broad effects on all who produce or consume goods and services that are traded internationally. Thus, the statement that no government can be indifferent to the exchange rate is as much a political as an economic observation.

\section{Flexible Rates and Inflation}

Few characteristics of modern society have failed to be identified as a cause of inflation, and flexible rates are no exception. The fact that the present inflation originated and developed under pegged rates at least

I/ It is interesting that one of Keynes' proposals for dealing with this problem, namely a "substantial Government transfer tax on all transactions" to discourage the "predominance of speculation over enterprise" in the stock market, has recently been repeated by James Tobin for exchange market transactions in his forthcoming paper in the Eastern Economic Journal "A Proposal for International Monetary Reform." 
limits the extent to which flexible rates can be identified as a possible culprit. Even among those, however, who have no doubt that persistent increases in prices in terms of any particular currency cannot occur unless the authorities responsible for that currency follow accomnodating policies, there are some who argue that there are inflationary risks associated with flexible rates. These arguments are all variants of the notion that it is harder to maintain the discipline of prudent monetary and fiscal policies under flexible rates than under fixed rates.

It has often been suggested, for example, that changes in exchange rates can exercise asymmetrical effects. It is argued $\underline{1 /}$ that nominal prices in goods markets are inflexible downward, so that initially the increase in the domestic prices of goods tends to be larger in depreciating countries than the decrease in their prices in appreciating countries. Whether this is so is arguable, $2 /$ but in any case a permanent effect on the overall price levels in the two countries is not to be expected as long as no change is made in their demand-management policies. Thus, the argument has to be pushed one step further.

The second level of the argument is that the money wage rate is inflexible downward. 3/ Thus, a fall in the domestic prices of traded goods leads

1/ A recent version of this position is attributed to Laffer and Mundell by Wanniski (1974).

2/ For a discussion of the empirical evidence on this point, see Crockett and Goldstein (1976).

$3 /$ It has been pointed out that given prevailing inflationary conditions, the inflexibility problem is not relevant since there is sufficient room for rates of change of prices and money wages to be reduced because of exchange rate movements without ever becoming negative (see, for example, Claasen (1976)). This point is not crucial, however, since the downward inflexibility may apply to some extent to the rate of change of the money wage rate as well as to its level. 
to a fall in profit margins and in the level of economic activity in the appreciating country, while in the depreciating country a rise in wages in response to the depreciation reduces any increase in profit margins or in the level of economic activity. There is thus a fall in the aggregate level of economic activity for the two countries taken together. Under such conditions, the monetary and fiscal authorities may take expansionary action, and exchange rate variations could thus lead to more expansionary policies. and thus to a higher rate of inflation for the world as a whole.

A criticism of the Laffer-Mundell line of argument has been raised by Crockett and Goldstein (1976). This criticism is that the exchange rate instability under discussion is to a large extent short run in nature. Given the slowness of the effects of exchange rate changes on activity levels and resource allocation in the goods markets, it is unlikely that short-run exchange rate movements have any noticeable effects on these variables and unemployment. There is, therefore, no reason to suppose that the authorities will adopt more expansionary policies in response to week-to-week or month-to-month fluctuations. This general point is valid, but there are also cases of longer-run exchange rate instability.

It has also been argued that undue reliance on the exchange rate to correct certain external and domestic imbalances can push a country into a vicious circle of depreciation and inflation. Typical cases are those where labor unions succeed in obtaining an increase in the money wage rate that exceeds the increase in the marginal value product of labor, or where an exogenous shock, such as the oil price increase of 1973 , leads to a . 
deterioration in the terms of trade. If real wage rates are inflexible downward and demand-management policies are accommodating, then currency depreciation can lead to price increases owing to the presence of imported goods in the price index, and this in turn leads to higher increases in wages that lead to higher prices, more depreciation, and a further feedback to prices, wages, and the exchange rate.

Asymmetrical price and wage effects and vicious circles would have very limited effects on inflation if the authorities did not accomodate incipient domestic costs and price increases by following expansionary monetary policies. Thus it is demand-management policies rather than flexible rates that are the fundamental factor, and the case for a positive association of flexible rates and inflation rests on the view that there may be occasions in which the authorities feel constrained to accomnodate incipient domestic cost and price increases rather than accept temporary unemployment. Against this must be counterbalanced the greater freedom stable countries have had to pursue prudent policies, and thereby to enjoy a virtuous circle of currency appreciation and falling rates of price increase. It should also be noted that depreciating rates have not freed governments from pressures to take strong action to check adverse developments. Indeed, rapid depreciation is widely regarded as clear evidence of imprudent policies, and the fact that an underlying disequilibrium is not masked by a fixed rate and restrictions on the flow of goods and capital has in a number of cases played a positive role in bringing about adjustment. 


\section{The Search for Greater Exchange Rate Stability}

While it is too early to draw any final conclusions, there is no doubt that there has been disillusionment with the floating rate system. It is true that floating rates have cleared exchange markets without traditional balance of payments "crises," and that flexibility has made it easier for rates of inflation to differ from country to country. These are, however, mixed blessings if the rates at which exchange markets clear fluctuate widely and if, as is increasingly recognized, the freedom to inflate is a form of license which, if exercised, brings more costs than benefits. A country can avoid importing inflation, but even in that respect the system is not without its dangers if the exchange rate appreciation goes to the point, as in the case of Switzerland in 1978, of threatening industrial effects which might prove to be excessive over the long run. Finally, given the lags in the response of goods markets to exchange rate changes and other factors, external adjustment problems have persisted and the ability of national authorities to stabilize growth rates has turned out to be about as limited under flexible rates as it was under the par value system. It is true that the more extreme fears on which the case against flexible rates was built have not proved to be justified. Foreign exchange markets have adapted to the flexible rate environment, and so far there is little evidence that the flows of foreign trade or international capital movements have been significantly curtailed in response to exchange rate fluctuations. The marked short-run variability of rates has, nevertheless, generated hostility toward the flexible rate system. 
This hostility might well have been contained if the exchange rate instability had been limited to the first two or three years of floating and if, as seemed possible in 1975 and 1976, the system had tended to settle down. The events of 1977-79, however, have rekindled the fears that instability may be an inherent characteristic of the floating system. Thus, as a result of both experience and analysis, it is less clear now than it appeared a few years ago that if the major industrial countries were to succeed in achieving orderly economic growth with reasonable price stability, this would automatically bring exchange rate stability. In short, it now appears that national stability is a necessary, but probably not a sufficient, condition for exchange rate stability. This has contributed to skepticism among policymakers on the benefits of a floating rate system and encouraged support for greater fixity. The renewed attempt to develop a European Monetary System is one example of this search for stability. A. The Continuing Need for Exchange Rate Flexibility While there is a strong and widespread desire for greater stability of exchange rates, there is no escaping the fact that this implies a substantial measure of domestic economic stability, and such stability is not going to be easy to achieve over a wide range of countries. It might be thought that the widespread view that there is no significant trade-off between inflation and unemployment over the long run would make it easy to muster support for policies that could bring economies down from a high rate of inflation to a significantly lower one. But just as the knowledge that freer trade increases welfare does not eliminate the short-run adverse effects arising from the reduction of trade barriers, and therefore does 
not remove opposition to tariff cutting, so the fact that there are serious transitional difficulties in bringing down rates of wage and prices increase has been a major inhibiting factor in achieving national stability.

Part of the difficulty arises from the nature of labor markets where, even in the absence of formal union contracts, there is a long-term relationship between employers and employees which is of a contractual character. $1 /$. Without a strong anti-inflation consensus, it is difficult to convince employers and their employees that an announced intention to curb expenditure and reduce inflation really means that the economic climate has changed, and that major adjustments in price expectations and wage demands should be made. If those setting wages and salaries are not convinced, wage settlements, whether unionized or non-unionized, will not decline rapidly enough to prevent a sharp rise in unemployment. The rise in unemployment brings strong pressure to bear on governments to reverse its restrictive policies, and if this happens it becomes increasingly difficult to mount a convincing anti-inflation program on a later occasion. A number of countries have drifted into this kind of vicious circle and found it difficult in the extreme to extricate themselves. Other countries have been fortunate in having or developing public attitudes on

\footnotetext{
1/ Hicks (1932) drew attention to the special nature of labor markets in his early work on wage theory. Gordon (1974) provided a neoclassical explanation of the tendency of short-run adjustments to a fall in demand to come in the form of employment declines rather than wage changes and a more rudimentary presentation of the argument can be found in the 1972 Fund Report of the Canadian Prices and Incomes Commission (for which Gordon was a consultant). A number of others, including Baily (1974), Azariadis (1976), Barro (1977) and Fischer (1977) have discusșed the consequences that follow from the contractual nature of transactions in labor markets.
} 
inflation which have led to much more decisive results. In countries where it is generally agreed that inflation is a serious threat, then, if the government announces restraining action, the public is ready to believe that in fact money expenditure will be controlled and that it would be foolish not to adjust. The adjustment of employers and employees which then follows helps to prevent unemployment from rising to politically dangerous levels. There is therefore little pressure for a reversal of policy and this reinforces the anti-inflation program. The same countries that have benefited from public hostility to inflation have also had other advantages in achieving reasonable price stability with limited effects in terms of unemployment for their own nationals. Both the Federal Republic of Germany and Switzerland adjusted to a lower level of economic activity, in part by decreasing the number of foreign workers employed in their economies. In the case of Japan, the employment policies of firms are such that the number of firings have been limited. Thus, those that have the ability to control inflation have also been able to pass along some of the social costs to others, or have had social arrangements that limited the political risks of economic slack.

It is not to be expected that differences in rates of inflation among countries will be eliminated in the near future. The more stable countries will understandably be reluctant to follow policies that will lead to a return to significant rates of price increase. At the same time, a number of inflating countries have great difficulty in persevering with policies that would reduce their rates of inflation substantially over the next few years. Some believe that pegged rates in and of themselves 
would lead to the necessary conversion to a belief in reasonable price stablity in the latter countries. While there are some feedbacks from exchange rates to domestic decisions on inflation, in a world which is as far away as this one from belief in the verities of the gold standard or the sanctity of a particular exchange rate, it is unlikely that there will be a strong response to such a simple appeal. Thus, the need for a considerable measure of exchange rate flexibility is likely to remain for some years to come. Problems of Pegged Rate Systems

The justification for some form of pegging, or its approximation in the form of heavily managed floating, that would allow for the needed exchange rate flexibility while avoiding any undue variability is clear in principle. Given existing domestic and foreign circumstances and policies, there are adjustment paths for exchange rates that would minimize the adjustment costs of economies. Market forces may lead to different, more erratic adjustment paths. If the authorities had the objective of minimizing adjustment costs, and if they could discount temporary disturbances better than private market participants, they could steer rates more directly to their longer-run equilibrium levels. However, what if, as it appears likely, neither market participants nor the authorities have any precise view of what the longer-term equilibrium exchange rates are? Given that uncertainty, the authorities' stabilizing role does not derive from knowledge that is denied to market participants, but rather from the fact that the amount of resources available to them enable them to set the price, if that price is a reasonable one. 
As long as the rates set by the authorities are within the band constituted by what private market participants view as realistic exchange rates, then setting rates is simply a way of getting short-run expectations to coalesce on specific, if somewhat arbitrary, values. Smoothing out adjustment paths may, therefore, have little to do with having deeper insight than that of private market participants; it may simply call for a commitment on the part of the authorities to set and maintain reasonable exchange rates.

That a pegged rate system can be successful in terms of reducing short-run exchange rate instability has been demonstrated by the relative success of the snake arrangement for those that remained within it. There are, however, major risks in any governmental policy to control the exchange rate. The main risk arises from the tendency of the authorities to maintain excessive rate rigidity. It is not that the authorities will necessarily be unaware of the need for a rate change, although this is a problem, but rather that they often cannot resist the temptation to maintain an overvalued rate as a form of price control, or an undervalued rate as a form of production incentive. They may resist depreciation because such an event is viewed by the public, often rightly, as a sign that the authorities have followed inflationary policies. They may also resist an appreciation because it would be unpopular with those in export and import-competing industries. A formal pegged system, as opposed to a heavily managed float, seems particularly subject to this danger of excessive rate rigidity, since changes in pegged rates are more noticeable, and more politically difficult to make, than a gradual change in the intervention points under a managed float. 
Successful resistance to exchange rate change on one occasion encourages further resistance later, and the exchange system soon becomes increasingly fixed. If, however, the conditions for fixity are not met, the ultimate result is an exchange rate crisis followed by a major exchange rate movement. Private market participants soon lose any confidence they may have had in the ability of the authorities to set a rate that is realistic, and there may even be a presumption that, if a rate is set by the authorities, it is probably wrong.

It is this natural tendency of the authorities to resist market pressures even when they reflect changes in the underlying economic and financial conditions that led to the break up of the Bretton Woods system in the early 1970s, and, as Oort (1974), the former Dutch Treasurer-General, and others have noted, there is no indication so far that this tendency has disappeared. In fact, as noted in previous sections, while it is certainly true that floating rates have tended to be unstable, part of the instability experienced in exchange markets in recent years can be directly attributed to vain attempts by the authorities to maintain exchange rate rigidity in the face of changing underlying economic and financial conditions.

Even if this inherent bias toward fixity could be avoided, a pegged system remains difficult to manage. If there are disparities in policies and performance, changes in pegged rates have to be quite frequent. Those operating in exchange markets are therefore likely to be confronted every year, if not every few months, with situations in which rates are likely to change, and there is little doubt as to the direction such changes will 
take. This leads to protective steps by those with foreign exchange exposure, and they may be joined by others looking for a speculative gain. This problem can be avoided only by making more frequent changes in the peg which can therefore be so small that they are not worth anticipating. Under these circumstances, a pegged rate system tends to be transformed either into a gliding rate system or back into a floating rate system.

A number of countries, of course, do at present peg their currencies to a single currency or a basket of currencies, and do so with underlying conditions that lead to periodic devaluations. These are generally countries, however, with relatively undeveloped financial markets. It is not clear that pegged rates among major industrial countries could be subject to frequent variations by significant amounts without leading to exchange markets that were even more nervous and volatile than they are under managed floating. This may well set limits to what might be called "premature pegging."

It might appear that a gliding rate system would be the solution because it would reduce the risks of inappropriate rates by taking into account automatically some of the changes in underlying economic and financial conditions. The differences with a pegged rate system, however, are more a matter of degree than of kind. The difficulty in a gliding peg system lies in the choice of the formula. Since there are no simple objective indicators that can be relied upon to reflect the changing underlying conditions, exchange market disequilibria can build up under a gliding rate system nearly as fast as under a pegged system. For example, an attempt to fix the rate between the yen and the U.S. dollar since the early 1970 s 
on the basis of some indicators of relative domestic prices of manufactures or relative unit labor costs in manufacturing would have been disastrous. Domestic prices and unit labor costs tended to rise faster in Japan than in the United States during that period so that the value of the yen in terms of U.S. dollars would have been gliding downward on the basis of such indicators. More sophisticated indicators can be designed (see Artus (1978) and Kenen (1975)), but ultimately there is always the same need for discrete changes in the rate at not infrequent intervals. Flexibility is not the only condition required for the achievement of greater exchange rate stability. As pointed out in Part II, monetary and financial factors play an important role in the short-run determination of the exchange rate, and if greater exchange rate stability is to be achieved, careful attention must be given by the authorities to exchange market developments in reaching decisions on monetary policy.

Over the years, monetary authorities have adopted various indicators as a guide for their actions. Under the international gold standard, the maintenance of that standard was the prime objective of policy, and the international position was crucial in determining the discretionary actions of central banks. Under looser international arrangements, central banks felt they had greater, though limited, freedom to focus on the credit conditions, or more narrowly on the interest rates, that would contribute to 
domestic objectives. These indicators had their weaknesses, and were particularly open to misinterpretation during periods of inflation. More recently the emphasis has been on monetary quantities, with a number of major industrial countries establishing targets for various monetary magnitudes. While adherence to monetary targets has proved to be difficult, an approach of this kind has seemed helpful in moving in the direction of greater stability. Experience and analysis suggest, however, that if greater stability of exchange rates is to be achieved, whether under managed floating or some form of pegging, the authorities will need to pay closer attention to international considerations in making short-run decisions on demand-management policies. Indeed, the exchange rate may of ten perform as a better indicator for monetary policy than interest rates or monetary aggregates, in particular in periods where the demand for money is unstable and the monetary aggregates subject to statistical problems. There is some evidence that in the recent period national authorities have moved in that direction and have been giving greater thought to exchange market develop$\because$ ments in determining monetary policy. 


\section{References.}

Argy, Victor, 1975, "The Dynamics of Monetary Policy under Flexible Exchange Rates: An Exploratory Analysis," in Papers in Monetary Economics, Reserve Bank of Australia, Sydney, pp. 1-42.

Artus, Jacques R., 1976, "Exchange Rate Stability and Managed Floating: The Experience of the Federal Republic of Germany," IMF Staff Papers 23, July, pp. 312-33.

, 1978, "Methods of Assessing the Long-Run Equilibrium Value of an Exchange Rate," Journal of International Economics 8 , May, pp. 277-99.

, 1979, "Persistent Surpluses and Deficits on Current Accounts Among Major Industrial Countries: A Discussion of Policy Issues," mimeo, International Monetary Fund.

Artus, Jacques R. and Andrew D. Crockett, 1978, "Floating Exchange Rates and the Need for Surveillance," Essays in International Finance No. 127, Princeton, N.J., Princeton University, International Finance Section.

Azariadis, Costas, 1976, "On the Incidence of Unemployment," Review of Economic Studies 43, February, pp. 115-25.

Baily, Martin N., 1974, "Wages and Employment under Uncertain Demand,". Review of Economic Studies 41, January, pp. 37-50.

Ball, Robert J., The International Linkage of National Economic Models, ed. by Robert J. Ball, Amsterdam.

Barro, R. J., 1977, "Long-Term Contracting, Sticky Prices, and Monetary Policy," Journal of Monetary Economics 3, July, Pp. 305-16.

Beenstock, M. C. and A.P.L. Minford, 1976, "A Quarterly Econometric Mode1 of Trade and Prices 1955-1972," in J. M. Parkin and G. Zis, eds., Inflation in Open Economies, University of Manchester, 1976.

Bilson, John F. 0., 1979, "Recent Developments in Monetary Models of Exchange Rate Determination," IMF Staff Papers 26, June, ---.

Black, Stanley W., 1977, Foreign Exchange Rates and National Economic Policy, Yale University Press, New Haven and London. 
Branson, William H., 1976, "Asset markets and relative prices in exchange rate determination," mimeo, Institute for International Economic Studies, Stockholm.

, H. Halttunen and P. Masson, 1977, "Exchange Rates in the Short Run," European Economic Review 10, December, pp. 303-24.

Brillembourg, Arturo, and Susan M. Schadler, 1979, "A Model of Currency Substitution in Exchange Rate Determination 1973-1978," IMF Departmental Memorandum No. 79/12 (February 23, 1979).

Burtle, James, and Sean Mooney, 1978, "International Trade and Investment under Floating Rates: The Reaction of Business to the Floating Rate System," in Exchange Rate Flexibility, Proceedings of a Conference Sponsored by the American Enterprise Institute for Public Policy Research and the U.S. Department of the Treasury, edited by Jacob S. Dreyer and others, Washington, D.C.

Claasen, Emil-Maria, 1976, "World Inflation Under Flexible Exchange Rates," Scandinavian Journal of Economics 78, No. 2, pp. 346-75.

Cornell, Bradford, 1977, "Spot Rates, Forward Rates and Exchange Market Efficiency," Journal of Financial Economics 5, August, pp. 55-65.

Crockett, Andrew D., and M. Goldstein, 1976, "Inflation Under Fixed and Flexible Exchange Rates," IMF Staff Papers 23, November, pp. 509-44.

Deppler, Michae1 C. and Duncan Ripley, 1978, "The World Trade Mode1Merchandise Flows," IMF Staff Papers 25, March, pp. 147-206.

Dooley, Michael P., and Jeffrey Shafer, 1976, "Analysis of Short-Run Exchange Rate Behavior, March 1973 to September 1975," mimeo, Federal Reserve Board.

Dornbusch, Rudiger, 1976, "Expectations and Exchange Rate Dynamics," Journal of Political Economy 84, December, pp. 1161-76.

, 1978, "Monetary Policy under Exchange Rate Flexibility," in the Federal Reserve Bank of Boston Conference Series No. 20, Managed Exchange-Rate Flexibility: The Recent Experience (October 1978).

, 1977, "What Have we Learned from the Float?", unpublished, paper prepared for the Academic Consultants' Meeting with the Federal Board of Governors, February 24.

, and Paul Krugman, 1976, "Flexible Exchange Rates in the Short Run," Brookings Papers on Economic Activity No.3, pp. 537-75. 
Economistes Belges de Langue Francaise, 1977, Economies Ouvertes Face aux Mutations Internationales - Rapport du $2 \mathrm{e}$ Congres des Economistes Belges de Langue Francaise, Centre Interuniversitaire de Formation Permanente.

Fischer, Stanley, 1977, "Comment on Barro's Article," Journal of Monetary Economics 3, July, pp. 317-23.

Fleming, J. Marcus, 1962, "Domestic Financial Policies Under Fixed and Under Floating Exchange Rates," IMF Staff Papers 9, November, pp. 369-80.

Friedman, Milton, 1953, "The Case for Flexible Exchange Rates," in Milton Friedman, Essays in Positive Economics, Chicago, University of Chicago Press, pp. 157-203.

, 1966, "Comments," in Guidelines, Informal Controls, and the Market Place, ed. by George P. Shultz and Robert Z. Aliber, The University of Chicago Press, Chicago, pp. 55-62.

, 1969, "Discussion of Kindleberger's Article," in the Federal Reserve Bank of Boston Conference Series No. 2, The International Adjustment Mechanism (October 1969), pp. 109-19.

Gordon, Donald F., 1974, "A Neo-Classical Theory of Keynesian Unemployment," Economic Inquiry 12, December, pp. 431-59.

Girton, Lance and Don Roper, 1976, "Theory and Implications of Currency Substitution," International Finance Discussion Paper No. 56, Board of Governors of the Federal Reserve System (August 1976).

Haberler, Gottfried, 1979, "Flexible Exchange Rate - Theories and Controversies Once Again," in the Memorial Volume for Egon Sohmen, forthcoming.

Hicks, John R., 1932, The Theory of Wages, MacMillan, London.

Hooper, Peter, and S. W. Kohlhagen, "The Effects of Exchange Rate Uncertainty on the Prices and Volume of International Trade," mimeo.

International Monetary Fund, 1978, The Rise in Protectionism, IMF Pamphlet Series, No. 24, Washington, D.C.

Isard, Peter, 1978, "Exchange-Rate Determination: A Survey of Popular Views and Recent Models," Princeton Studies in International Finance No. 42, Princeton, N.J., Princeton University, International Finance Section. 
Johnson, Harry G., 1957, "Towards a General Theory of the Balance of Payments," in Harry G. Johnson, International Trade and Economic Growth, Harvard University Press, Cambridge, Mass.

, 1969, "The Case for Flexible Exchange Rates, 1969," Review of the Federal Reserve Bank of St. Louis 51, June, pp. 12-24.

Kareken, John, and Neil Wallace, 1978, "International Monetary Reform: The Feasible Alternatives," Federal Reserve Bank of Minneapolis Quarterly Review (Summer 1978), pp. 2-7.

Kenfen, Peter B., 1975, "Floats, Glides and Indicators," Journal of International Economics 5, May, pp. 107-51.

Kindleberger, Charles P., 1969, "The Case for Fixed Exchange Rates, 1969," in the Federal Reserve Bank of Boston Conference Series No. 2, The International Ad justment Mechanism (October 1969), pp. 93-108.

, 1976, "Germany's Persistent Balance-of-Payments Disequilibrium Revisited," Banca Nazionale del Lavoro Quarterly Review 29, June, pp. 135-64.

Kouri, Pentti J. K., 1976, "Exchange Rate Expectations and the Short Run and the Long Run Effects of Fiscal and Monetary Policies under Flexible Exchange Rates," Scandinavian Journal of Economics 78, No. 2, pp. 280-304.

Kravis, Irving B., Robert E. Lipsey and Eliot Kalter, 1977, "Export Prices and Exchange Rates," National Bureau of Economic Research Working Paper No. 182.

, and Robert E. Lipsey, 1977, "Export and Domestic Prices Under Inflation and Exchange Rate Movements," National Bureau of Economic Research Working Paper No. 176.

McKinnon, Ronald I., 1976, "Floating Exchange Rates 1973-74: The Emperor's New Clothes," in Karl Brunner and Allan Meltzer, eds., Institutional Arrangements and the Inflation Problem, North-Holland, Ansterdam.

, 1978, "Exchange-Rate Instability, Trade Balances, and Monetary Policies in Japan and the United States," mimeo.

, 1979, Money in International Exchange: The Convertible Currency System, Oxford University Press. 
Modigliani, Franco, and Hossin Askari, 1973, "The International Transfer of Capital and the Propagation of Domestic Disturbances Under Alternative Payments Systems," Banca Nazionale del Lavoro Quarterly Review, December, pp. 295-310.

Mussa, Michael, 1976, "The Exchange Rate, the Balance of Payments and Monetary and Fiscal Policy under a Regime of Controlled Floating," Scandinavian Journal of Economics 78 , No. 2, pp. 229-48.

Nordhaus, William D., 1978, Testimony Before the Subcommittee on Foreign Economic Policy of the Committee on Foreign Relations (June 22, 1978), U.S. Congress.

Oort, Coenraad J., 1974, "Steps to International Monetary Order," Proceedings of the Meeting of the Per Jacobsson Foundation (October 1974), Washington, D.C. Pp. 7-52.

Oppenheimer, Peter, et al., 1978, Business Views on Exchange Rate Policy, Confederation of British Industry, July, London.

Phelps, Edmund S., 1972, Inflation Policy and Unemployment Theory: The Cost-Benefit Approach to Monetary Planning, Norton, New York.

Phillips, A. W., 1958, "The Relation between Unemployment and the Rate of Change of Money Wage Rates in the United Kingdom, 1867-1957," Economica N.S. 25, November, pp. 283-99.

Polak, J. J., 1957, "Monetary Analysis of Income Formation and Payments Problems," IMF Staff Papers 6, November, reprinted in The Monetary Approach to the Balance of Payments, International Monetary Fund, eds., Washington, D.C.

Porter, Michael, 1977, "The Exchange Rate and Portfolio Equilibrium," mimeo, Monash University.

Rhomberg, Rudolf R., 1964, "A Model of the Canadian Economy Under Fixed and Fluctuating Exchange Rates," The Journal of Political Economy 72, February, pp. 1-31.

Rhomberg, Rudolf R., and H. Robert Heller, 1977, "Introductory Survey," in The Monetary Approach to the Balance of Payments, International Monetary Fund, Washington, D.C., pp. 1-14.

Ripley, Duncan M., 1979, "The Transmission of Fluctuations in Economic Activity: Some Recent Evidence," in The Federal Reserve Bank of Boston Conference Series No. 20, Managed Exchange-Rate Flexibility: The Recent Experience (October 1978). 
Roosa, Robert V., 1967, "Second Lecture," in The Balance of Payments: Free Versus Fixed Exchange Rates, American Enterprise Institute, Washington, D.C., pp. 27-67.

Schadler, Susan, 1977, "Sources of Exchange Rate Variability: Theory and Empirical Evidence," IMF Staff Papers 24, July, pp. 253-96.

Spitaeller, Erich, 1979, "Short-Run Effects of Exchange Rate Changes on the Terms of Trade, $1973(1)-1978(4), "$ mimeo, International Monetary Fund.

Stern, Robert M., Jonathan Francis and Bruce Schumacher, 1976, Price Statistics in International Trade - An Annotated Bibliography, The MacMillan Press, Ltd.

Tower, Edward, and Thomas D. Willett, 1976, "The Theory of Optimum Currency Areas and Exchange-Rate Flexibility," Princeton Special Papers in International Economics No. 11, Princeton, N.J.

Wanniski, Jude, 1974, "The Case for Fixed Exchange Rates," Wa11 Street Journal (June 14, 1974). 